\section{The Corpse in the Early Bronze Age. Results of Histotaphonomic and Archaeothanatological Investigations of Human Remains from the Cemetery of Franzhausen I, Lower}

\section{Austria}

\author{
Kirsten Mandl \\ Friederike Novotny \\ Maria Teschler-Nicola \\ Estella Weiss-Krejci
}

\begin{abstract}
It has recently been suggested by British archaeologists and anthropologists that mummification may have been widespread in Bronze Age Europe. This article presents the results of a study that, for the first time, investigates the question of whether the people who inhabited central Europe during the Early Bronze Age treated the bodies of their dead prior to deposition in order to prevent decay and preserve the soft tissue. The study relies on data from the cemetery of Franzhausen I in Lower Austria. The cemetery, excavated between 1981 and 1983, contained 714 Early Bronze Age graves and two pits with human remains. A sample of 22 skeletons from 22 graves was investigated using macroscopic, post-hoc archaeothanatological, and histotaphonomic analyses. Thin sections of the femora of 18 out of 22 individuals show high degrees of microbial tunnelling resulting from extensive putrefaction processes. Thin sections of femora from four individuals show less bioerosion indicating that the microbial invasion accompanying autolysis and decomposition was arrested at an early stage of the taphonomic process. Since the femora of these four individuals are partially discoloured green we lean towards the assumption that the good preservation of the internal bone microstructure was caused by a post-depositional uptake of heavy metals eroding from copper and bronze grave goods, mediated by a coffin environment.
\end{abstract}

\section{Keywords}

Funerary customs, mortuary archaeology, mummification, corpse preparation, archaeothanatology, bone diagenesis, histotaphonomy, Early Bronze Age, Lower Austria, Franzhausen I.
Zusammenfassung - Leichenbehandlung in der Frübbronzezeit. Resultate histotaphonomischer und archäothanatologischer Untersuchungen von menschlichen Überresten aus dem Gräberfeld von Franzhausen I, Niederösterreich

Jüngsten Theorien zufolge war Mumifizierung in der Bronzezeit in Europa weit verbreitet. Dieser Beitrag beschäftigt sich erstmals mit der Frage, ob die frühbronzezeitlichen Bewohner Zentraleuropas ihren Toten eine dem Erhalt des Weichteilgewebes förderliche Behandlung zukommen ließen. Die Daten stammen vom zwischen 1981 und 1983 ausgegrabenen Gräberfeld von Franzhausen I, das 714 frühbronzezeitliche Gräber und zwei Gruben mit menschlichen Skelettresten umfasst. Eine Stichprobe von 22 Skeletten aus 22 Gräbern wurde makroskopischen, post-hoc archäothanatologischen und histotaphonomischen Analysen unterzogen. Femur-Dünnschliffe von 18 der 22 Individuen zeigen einen hohen Grad an mikrobiellem Befall, der von Verwesungsprozessen herrührt. Femur-Dünnschliffe von vier Individuen weisen geringere Bioerosion auf, was darauf hinweist, dass Autolyse und Fäulnis begleitende mikrobielle Invasoren in einem frühen taphonomischen Stadium gestoppt wurden. Da die Femora dieser vier Individuen teilweise grün verfärbt sind, lässt sich die gute Erhaltung der inneren Knochenmikrostruktur mit der postdepositionalen Aufnahme von Schwermetallen aus kupfernen und bronzenen Grabbeigaben in einem Sargmilieu erklären.

\section{Schlüsselbegriffe}

Bestattungssitten, Gräberarchäologie, Mumifizierung, Leichenbehandlung, Archäothanatologie, Knochendiagenese, Histotaphonomie, Frühbronzezeit, Niederösterreich, Franzhausen I. 


\section{Introduction}

Processes of decomposition that take place in a dead body cannot be ignored by any society. A corpse does not quietly disappear. When rigor mortis ends, micro-organisms become highly active and the corpse begins to rot. The transformation is accompanied by bloating, the emanation of methane and a sulphurous smell, discolouration and the gradual detachment of the upper skin layer. ${ }^{1}$ In some instances the body may even produce a noise. ${ }^{2}$ All of these processes set the human senses on alert. Unless abandonment is an option, ${ }^{3}$ the biological reality of the dead body and its predisposition to decay means that it is imperative for survivors to do something about it. ${ }^{4}$ In today's Europe, the usual response is to remove the corpse from the place of death as soon as possible, to cool it and to store it in a morgue until its burial in the ground or cremation. In the prehistoric past, responses were probably much more variable, although exactly how variable is not always easy to determine. Today we are probably only looking at a small section of a much larger prehistoric population that, due to various taphonomic processes, has not been preserved in the archaeological record. ${ }^{5}$

\subsection{Treatment of the Corpse}

A society's response to the rotting corpse and the employment of distinctive post-mortem corpse treatments can provide a window into ancient attitudes towards death and the afterlife, offer an understanding of the relationship between body and 'soul'" and unmask group identities and social distinctions. $^{\text {? }}$

The minimum preparation ${ }^{8}$ afforded to a deceased person who died under regular circumstances usually consists of washing, shrouding, or dressing. In the archaeological

1 Iserson 1994, 42-43. - Hochmeister, Grassberger, Stimpfl 2007, 19. - Reiter, Ilbeygui, Stein 2007, 16-17.

2 It is no coincidence that in the past decaying corpses were instinctively feared in societies that practiced inhumation. BARBER 1987 argues that the belief in revenants arose out of misconceptions concerning the nature of decomposition.

3 In the past, abandonment of the corpse was a frequent response to death among hunter-gatherer populations: e.g. Fourie 1928, 95.

4 Nilsson Stutz 2008.

5 Parker Pearson 1999, 5. - Weiss-Krejci 2011a, 68. - Booth, MADGWick 2016, 14.

6 We would like to stress that the term 'soul' is probably inadequate as a description of prehistoric conceptions of the spiritual essence of a person.

7 Binford 1971. - CARr 1995. - SCHERER 2015.

8 We follow terminology by BINFORd 1971, 21 and CARr 1995, 130 who differentiate body preparation (e.g. washing) from body treatment (mummification, cremation, mutilation, etc.). SPRAGUE 2005, 70 calls them all 'body treatments'. record these forms of preparation can only be recognised under favourable conditions and through careful documentation and sampling during excavation. Treatments such as burning are easily recognised because they contribute to disarticulation and fragmentation and leave visible structural changes in the bones. Some forms of treatment such as active excarnation, dehydration, and chemical and thermal modification, ${ }^{9}$ may not be as apparent, especially when there is no disarticulation of the bones ${ }^{10}$ and only the soft tissue has been affected. Depending on the method, cut marks on the bones may be an indicator of either defleshing or of evisceration, especially when the thoracic viscera are also removed. In the latter case one would expect cuts on either the ventral side of the lower thoracic vertebrae or on the sternum and the ribs. However, it should be emphasised that evisceration is not a prerequisite for mummification. ${ }^{11}$ Enhanced dehydration can also be accomplished using the heat emanating from a fire and by draining the body fluids with a cloth or some other absorbent substance. ${ }^{12}$

Prehistoric mummified corpses that, over the course of centuries or millennia have been transformed into skeletons, can easily be mistaken for 'primary burials'. ${ }^{13}$ This 'mummy problem'14 can have serious implications for archaeological interpretation. If articulated, mummified, and macerated corpses are moved around ${ }^{15}$ but their treatment, manipulation, and re-deposition go unnoticed, the assumptions about the form of the original burial, the chronological relationship with associated artefacts, the level of people's engagement with the corpse, the identity of the deceased,

\section{Aufderheide 2003.}

10 According to recent taphonomic studies, Neolithic bodies from Çatalhöyük had probably been excarnated through partial consumption by vultures. Within the first days or weeks after death they still retained their ligaments and were deposited in a fully articulated state. - Pilloud et al. 2016.

11 We apply the term 'mummification' to all corpse treatments that result in soft-tissue preservation, be it via natural processes (as for example with Ötzi the Iceman) or by artificial means (Rameses II, Lenin, Evita Perón, etc.). However, we would like to emphasise that we only maintain this loaded term, which immediately brings to mind Egyptian or South American mummies, in the absence of an acceptable alternative.

12 See BECKETT et al. 2017 on mummification without evisceration among the Ibaloy of North Luzon, Philippines.

13 A primary burial is defined as an untreated corpse, deposited in the flesh shortly after death and not disturbed at any later point in time. - See also Pilloud et al. 2016, 3.

14 WeIss-KreJCi 2011a, 78. - WeIss-KreJCi 2011b, 166.

15 Desiccated articulated royal corpses of the Inca were regularly brought into the public domain in order to attend state ceremonies and answer important questions. - BRUNDAGE 1963, 179. - McEwAN 2006, 140. - Weiss-Krejci 2013. - For further examples see AufderHEIDE 2003. 
and even the archaeological age of the dead body may be misinterpreted.

\subsection{Mummification of the Corpse in the British Bronze Age} In the early 2000s, Mike Parker Pearson and his team were the first to address systematically the presence of mummified corpses in British Bronze Age contexts. ${ }^{16}$ Following the discovery of two Bronze Age skeletons from the site of Cladh Hallan (in the western isles of Scotland) which displayed signs of having been reassembled from the body parts of different individuals, histological analysis revealed that some of the bones had been subjected to only limited levels of microbial attack. This indicated that the bacterial invasion accompanying putrefaction had been arrested, possibly by preservation in an acid peat bog. ${ }^{17}$ In the course of this investigation, the team developed a method of histological analysis, which included bone thin section light microscopy, geared towards a consistent identification of deliberate mummification of the corpse. ${ }^{18}$ Over the last decade, using the premise that the microbial bioerosion of archaeological bone reflects the extent of early post-mortem decay, ${ }^{19}$ this approach has been refined to compare the patterns of bioerosion in the bones of ancient mummified corpses from various international collections.

The results show that bodies buried in sphagnum peat, corpses preserved by freeze-drying, and corpses that had been wrapped and buried deep in dry sand (as in the case of a Peruvian mummy), all display good preservation of the bone microstructure and similar diagenetic patterns. ${ }^{20}$ The comparison with diagenetic signatures in several British Bronze Age bodies suggests that some form of preservation of soft tissue had occurred before the final deposition of these corpses..$^{21}$ The processes involved in the intentional mummification of corpses in the British Bronze Age so far remain unknown.

\section{Mummification of the Corpse in Bronze Age Central Europe?}

In the case of prehistoric central Europe, evidence for the processing of bodies comes from an Early Iron Age burial

16 Parker Pearson et al. 2005. - Parker Pearson et al. 2007.

17 Parker Pearson et al. 2005. - Parker Pearson et al. 2007. Booth, Chamberlain, Parker Pearson 2015.

18 Parker Pearson et al. 2007. - Hanna et al. 2012. - Parker Pearson et al. 2013. - Booth, Chamberlain, Parker Pearson 2015. Воотн 2016.

19 Bell, Skinner, Jones 1996. - Jans et al. 2004. - Nielsen-Marsh et al. 2007. - Hollund et al. 2012. - White, Booth 2014.

20 Booth, Chamberlain, Parker Pearson 2015.

21 Booth, Chamberlain, Parker Pearson 2015. - Smith et al. 2016. mound near the Heuneburg, Germany. Here the presence of human blood in pottery vessels suggests that a form of exenteration may have been practiced, but this appears to be an isolated instance. ${ }^{22}$ The present study addresses, for the first time, the question of whether comparable practices existed in the central European Bronze Age (2150-1700/1650 BC). ${ }^{23}$

Wherever people applied artificial mummification in the past, they did not start doing so arbitrarily. Mummification always served some special need within the wider population. ${ }^{24}$ Although there seems to be no single purpose behind anthropogenic mummification, a cross-cultural examination - conducted by Arthur Aufderheide - of several ancient societies that practiced funerary mummification identified a combination of possible causal factors including social stratification, the rise of political elites, and population stress. ${ }^{25}$ Although social stratification was certainly present in the preceding Corded Ware (c. 2800-2500/2200 BC) and Bell Beaker (c. 2500-2150 BC) complexes, ${ }^{26}$ Early Bronze Age societies witnessed increasing hierarchisation and regionalisation, economic change, and population growth. Since differences in grave construction and quantity and quality of grave goods are visible in Early Bronze Age graves, we wondered if a diversification in funerary body treatments might have accompanied these socio-economic changes. In order to contribute to wider research objectives focussed on the treatment of corpses in the Bronze Age, ${ }^{27}$ we embarked on a preliminary study using data and skeletal material from the Early Bronze Age cemetery of Franzhausen I (henceforth FH I) in Lower Austria (Fig. 1).

FH I is one of the largest Bronze Age cemeteries in central Europe (Fig. 2) and archaeological and anthropological data have been presented in numerous unpublished and published works. ${ }^{28}$ Our choice of FH I was determined by

22 See Wiktorowicz et al. 2017.

23 Based on new radiocarbon dates, a chronology with a date of approx. 2150-1700 BC has recently been proposed by STOCKHAMMER et al. 2015. - On the Early Bronze Age in Austria, see Urban 2000. 24 Aufderheide 2003, 40.

25 E.g. early Egypt, the Inca, the Guanche; only the Chinchorro form an exception: AuFdERHEIDE 2003, 22-40.

26 Strahm 2002. - Bosch 2008. - Dates after Knipper et al. 2017. 27 Booth, Chamberlain, Parker Pearson 2015.

28 E.g. Berner 1988. - Teschler-Nicola 1988. - WiltschkeSchrotta 1988. - Schultz, Teschler-Nicola 1989. - Berner 1992. - Berner, WiltschKe-SchrotTA 1992. - Teschler-Nicola 1992. - Wiltschke-Schrotta 1992. - Stadler 2001. - Spatzier 2007. - Wilson 2007. - Keller, Teschler-Nicola 2013. - KreutZ 2014, 52, 93. - Neugebauer-Maresch 2016. 


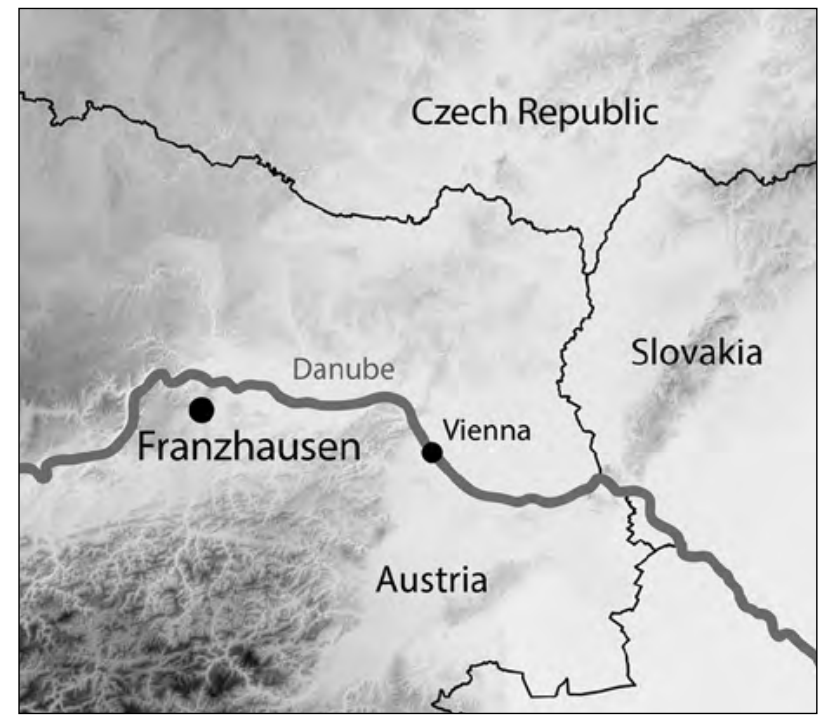

Fig. 1. Location of Franzhausen, Lower Austria (@ OREA, ÖAW).

the following factors: (1) thin sections of the bones of 22 individuals had been made and analysed in 1998 by the second author of this study; these previously unpublished data became available for re-analysis and publication; (2) the bones are kept at the Natural History Museum of Vienna (NHM) and most of them were available for re-examination; (3) colour slides of the skeletons as found in situ between 1981 and 1983 are held by the Federal Monuments Office at the Mauerbach depot and were available for post-hoc archaeothanatological investigation; (4) in the case of some skeletons, such as those from graves $17,97,256$, and 347 , the pronounced compression of the body and the extreme flexion of the legs attracted our attention (Fig. 3/a-c). Although wrapping may form a distinct treatment independent from body processing, one way to facilitate tight wrapping could be by means of mummification or excarnation.

\subsection{The Cemetery of Franzhausen I}

The cemetery of FH I lies within the cadastral communities of Franzhausen and Wagram an der Traisen. During the construction of highway S 33 between Krems and St. Pölten, archaeological excavations were conducted between 1981 and 1983 under the direction of Johannes-Wolfgang Neugebauer (Fig. 4/a-b).

The oldest burial (Fig. 5/a) in the cemetery belongs to the Baden period, followed by thirteen west-east-oriented single graves of the Corded Ware Culture group. ${ }^{29}$ Two pits

29 Lobisser, Kern 2017, Fig. 2. and 714 graves with c. 737 individuals were assigned to the Early Bronze Age. ${ }^{30}$ The Bronze Age cemetery displays typical gender-specific funerary arrangements, usually single inhumations in flexed positions. Exceptions include double and triple inhumations as well as single graves with isolated bones from a second individual. Males were usually placed on the left side of the body with the head turned north and the face aligned east (Fig. 5/b), while females were arranged on their right side with their head pointing south and the face also looking eastwards (Fig. 5/c) ${ }^{31}$ The latest graves in the cemetery belong to the Iron Age (c. thirteen Hallstatt and two La Tène-period graves) (Fig. 5/d). In addition, postholes in various arrangements and other negative features of undetermined nature were recorded (Fig. 2). The number of negative features totals $1013 .{ }^{32}$

The Early Bronze Age cemetery was in use over a period of at least 300 years, starting in about $2050 \mathrm{calBC}$, and belongs to the Unterwölbling and Böheimkirchen culture groups. ${ }^{33}$ By calculating the number of graves, mortality rates, and time horizons, it is suggested that the population of the farming settlement near the cemetery consisted of several extended families that, at any given time, numbered around 110 people. ${ }^{34} \mathrm{~A}$ social hierarchy within the population of FH I is suggested ${ }^{35}$ by differing grave depths, the presence of tree log coffins (usually made from oak), and varying numbers and quality of grave goods including: animal remains; ceramic containers; stone, copper, and bronze weapons and tools; bone and bronze pins; jewellery made from bone, shell, bronze, gold, amber, and glass. The average burial depth was $131 \mathrm{~cm},{ }^{36}$ although the depth of some graves - probably of those occupying positions of elevated socio-economic status - could be more than four meters. ${ }^{37}$

30 During excavation, all negative features (i.e. graves, pits with and without human bones, and postholes) were referred to as 'Verfärbung' (= discolouration) and numbered sequentially. Herein, we use the assigned numbers to refer to the graves and the individuals found in them.

31 Neugebauer, Neugebauer -Maresch 1988. - Neugebauer, Neugebauer 1997.

32 Neugebauer, Neugebauer 1997, 21.

33 Neugebauer 1991. - Sprenger 1999, 22.

34 Teschler-Nicola 1988.

35 Neugebauer 1987. - Neugebauer, Neugebauer -Maresch 1988.

36 Measured from the upper surface of the modern topsoil (Humusoberkante) to the bottom of the grave: Neugebauer, Neugebauer 1997, 24.

37 Grave 853 ( $429 \mathrm{~cm}$ below the modern topsoil): Neugebauer, Neugebauer 1997, 469. 


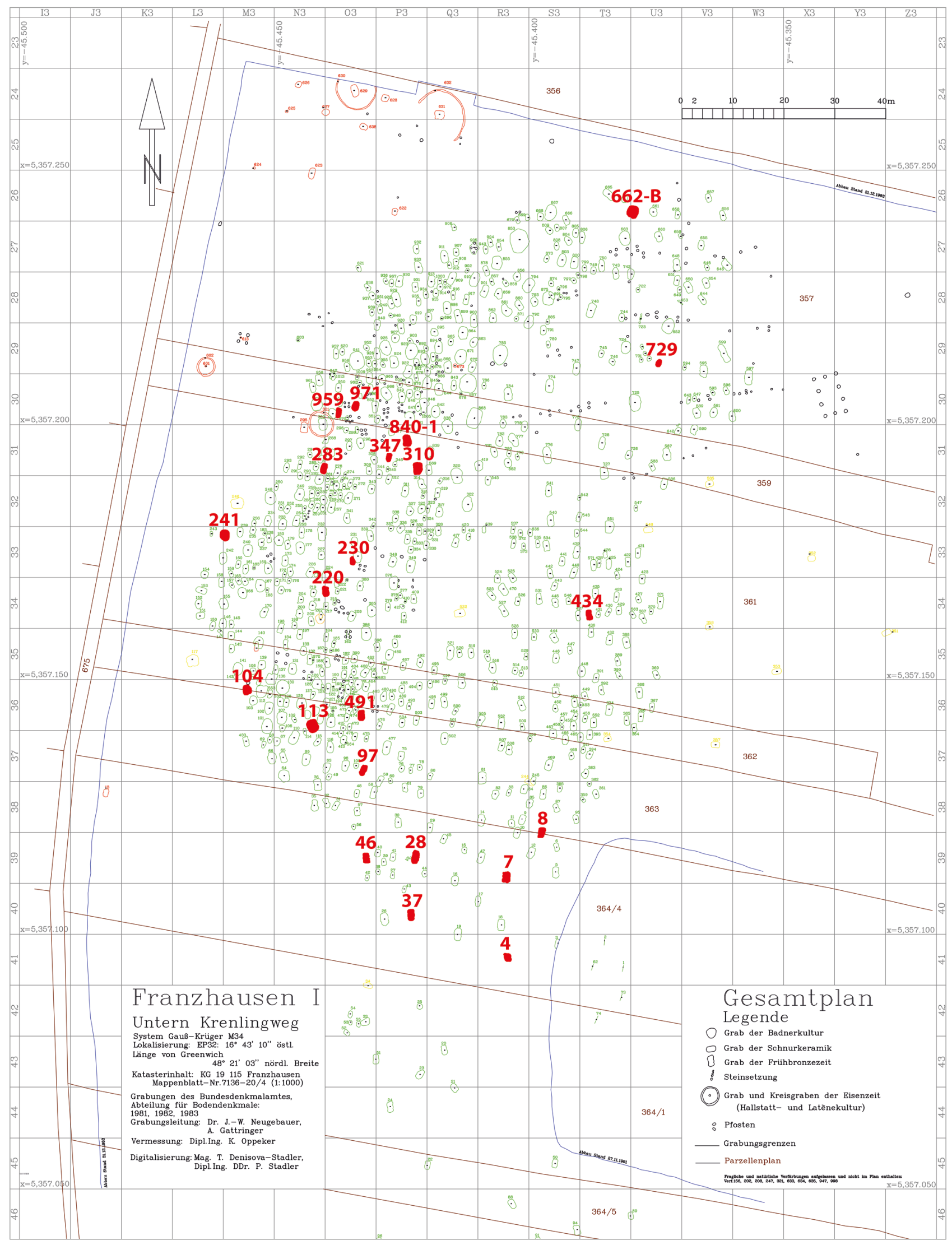

Fig. 2. Plan of the Franzhausen I cemetery. Bronze Age graves are coloured in green (plots 364/5 and 364/2 cropped at the southern end; hence six graves missing from this version) (based on Neugebauer, Neugebauer 1997, Vol. 2, Plan 1; courtesy of Federal Monuments Authority Austria, Archive Mauerbach). 


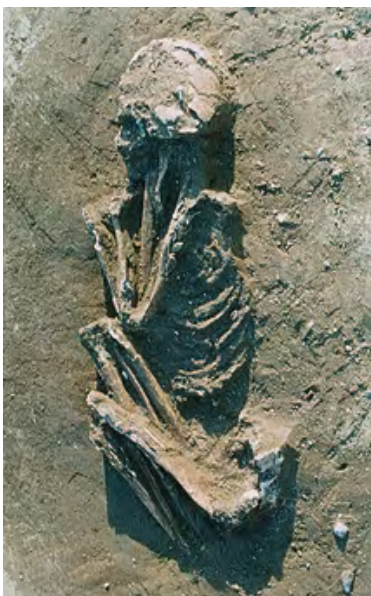

a

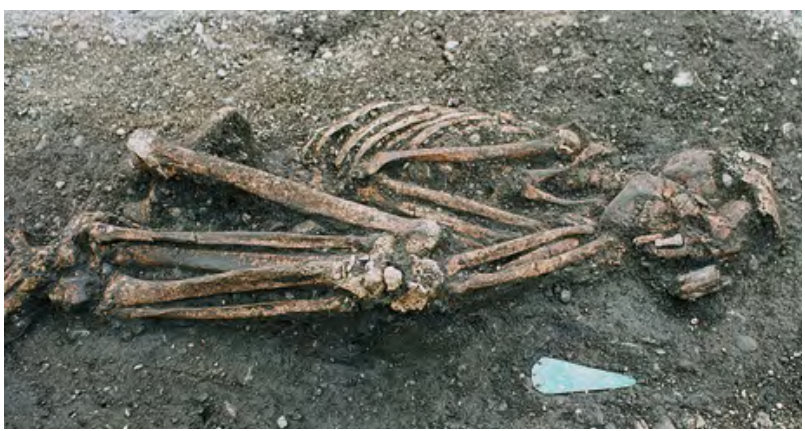

C

Fig. 3. Skeletons with pronounced compression of the thoracic cage and extreme flexion of the legs. - a. Grave 17: adult, head pointing S, face looking E. - b. Grave 256: juvenile, head pointing N, face looking W (which is an exception). - c. Grave 347: adult male, head pointing N, face looking E (Photos: courtesy of Federal Monuments Authority Austria, Archive Mauerbach).

\subsection{Research Obstacles}

Although the publication ${ }^{38}$ of FH I is of excellent quality, there are some problems that should be noted. Approximately $75 \%$ of the graves at FH I had been opened and disturbed - probably as an act of grave robbery ${ }^{39}$ - during the Bronze Age. The disturbance, which was highly variable and ranged from slight to total, took place either within a relatively short time of deposition, before the body was skeletonised, or at a later date. ${ }^{40}$ Knowing whether, and at what point in time, disturbance had taken place is of importance. ${ }^{41}$ Bones from complete, articulated corpses show different forms of diagenetic alteration than disarticulated ones and early post-mortem disarticulation prevents the impact of soft-tissue putrefaction and thus the progress of

38 Neugebauer, Neugebauer 1997.

39 Neugebauer, Neugebauer 1997, 11. - Sprenger 1999.

40 Sprenger 1999, 26-42.

41 Aspöck, Banerjea 2016. bacterial attack on the bones. ${ }^{42}$ Hence, one prerequisite for recognising mummification is that the skeleton has been in an articulated state at the time of, and for some time after, deposition.

The question of whether bronze artefacts had been present in the grave is also significant because bronze and copper artefacts can assist in the preservation of bone. ${ }^{43}$ Whether bronze artefacts had been removed during the re-opening of graves, can, and has been, determined by the investigation of the presence of green bone discolouration. ${ }^{44}$ Calcium apatite can absorb metal elements from the surrounding environment, which results in infiltration and staining. That the green discolouration on the FH I bones was the result of contact with copper or bronze objects is not only supported by photographs from $\mathrm{FH} \mathrm{I}^{45}$ but also by a study ${ }^{46}$ of animal bones from a medieval copper alloy workshop in Paris. The study demonstrates a connection between green staining on bones and heavy metal uptake, because all of the green coloured bones were significantly enriched with copper and zinc. ${ }^{47}$

The properties of the soil must also be taken into account. Although soil characteristics may not affect early diagenetic processes, ${ }^{48}$ soil $\mathrm{pH}$ can play a role in bone diagenesis over longer periods of time. While acidic environments mainly affect mineralised tissues, alkaline environments affect the organic components of the bone, predominantly the collagen. ${ }^{49}$ Post-depositional depletion and transportation of soils can have an effect on the bones..$^{50}$ The permeability of the soil is also important because water is an important factor in almost all of the chemical reactions that affect the preservation of skeletal remains. ${ }^{51}$ According to

42 See Rodriguez, Bass 1983. - Child 1995. - Bell, Skinner, Jones 1996. - FERnÁndez-Jalvo et al. 2010. - Simmons et al. 2010. WHite, ВоOTH 2014.

43 Pfeiffer 2000. - Assis et al. 2015. - The anti-adherence and bactericidal effects of copper have been proven by an in-vitro study of Staphylococcus epidermidis in silicone breast implants. On test specimens with higher copper concentration, a larger amount of dead bacteria tended to be found than on the samples with the lower copper concentration: SCHEDEL 2012.

44 Sprenger 1999, 43-60.

45 See Grave 491 in Fig. 21.

46 Undertaken by MüLlER et al. 2011, 44.

47 Müller et al. 2011, 44.

48 MANT 1987.

49 Fernández-Jalvo et al. 2002, 358. - Nielsen-Marsh et al. 2007. 50 Usai et al. 2014. - Aspöck, BanerJea 2016.

51 Garland 1987. - Hedges, Millard 1995. - Fernández-Jalvo et al. 2002. - Turner-Walker 2008, 22. - Assis et al. 2015. - The effect of sealed, wet, and anaerobic environments on dead bodies is perfectly demonstrated by the well-preserved corpses from the south Scandinavian Bronze Age barrows: Holst, Breuning-Madsen, Rasmussen 2001. - Breuning-Madsen et al. 2003. 


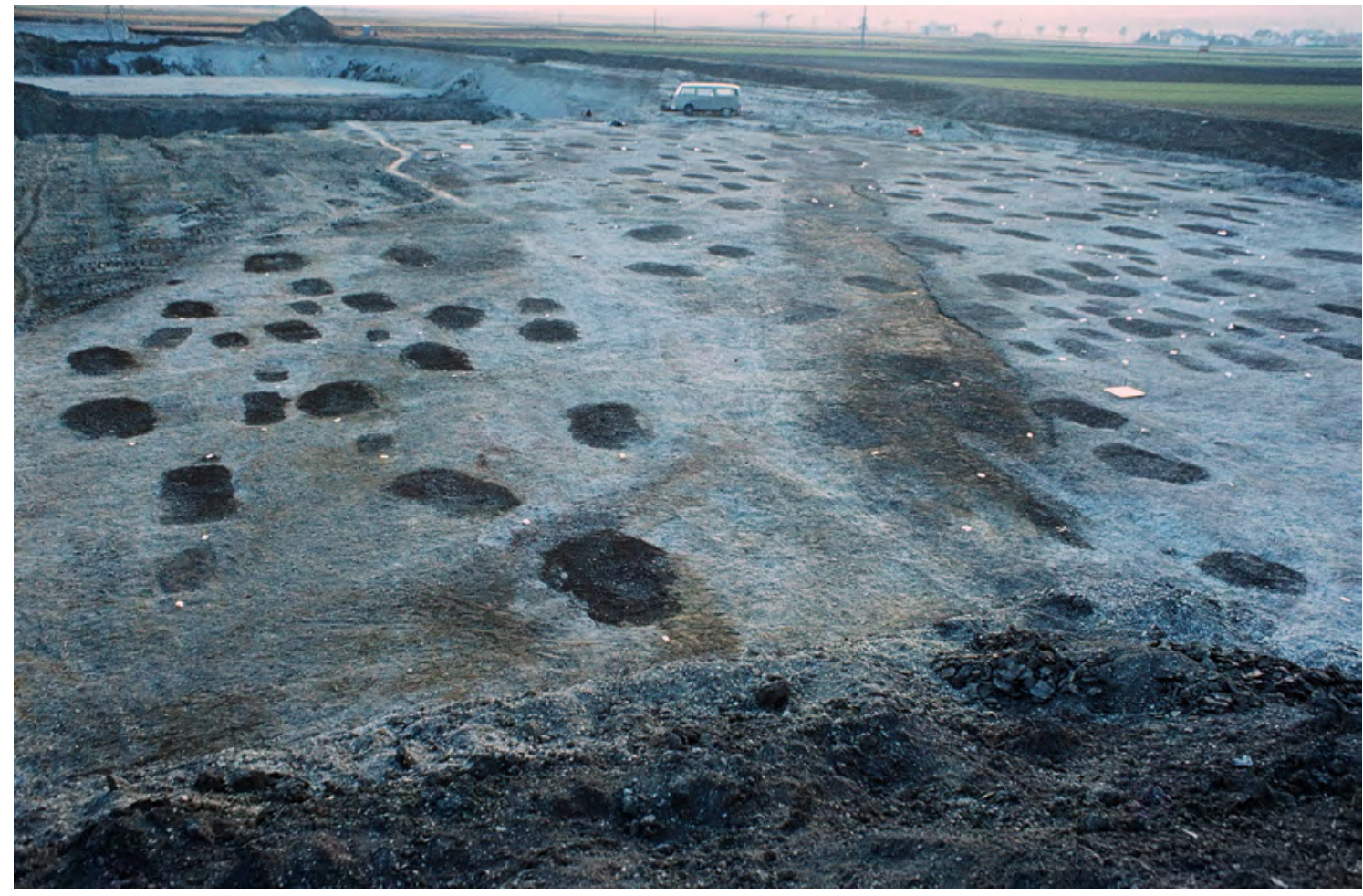

a

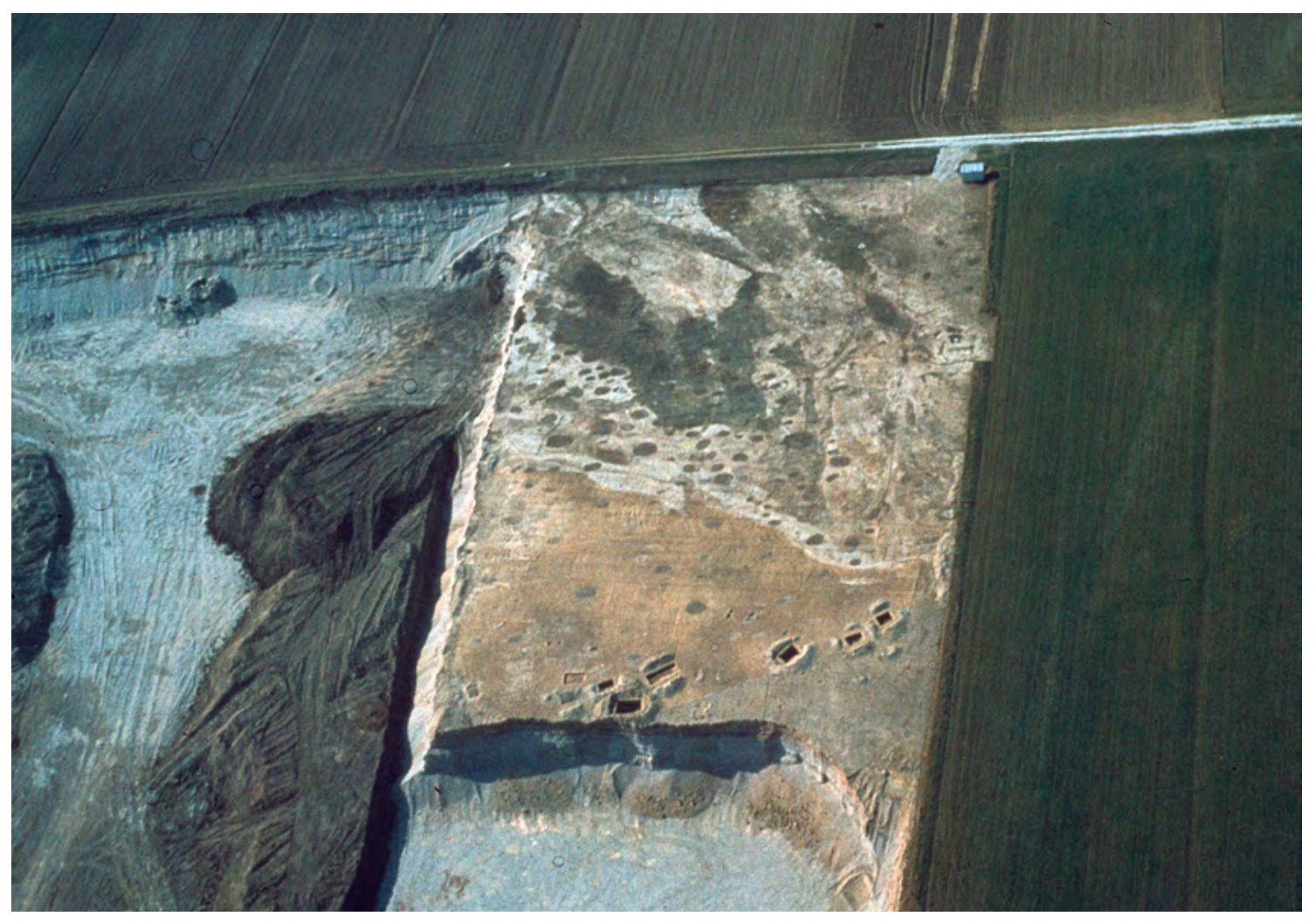

b

Fig. 4. - a. Traunfellner Enterprises gravel pit, plots 361, 362, and parts of 363, exposed cleaned surface, spring 1982 (Photo: J.-W. Neugebauer, courtesy of Federal Monuments Authority Austria, Archive Mauerbach). - b. Aerial photograph of the exposed hand-cleaned surface in plots 357 and 359, March 1983 (Photo: L. Beckel, courtesy of Federal Monuments Authority Austria, Archive Mauerbach). 


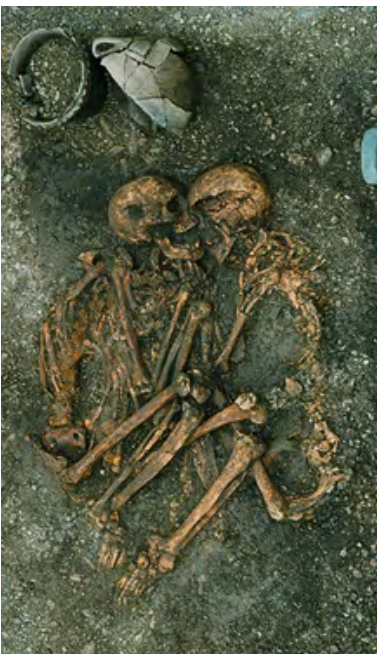

a



b

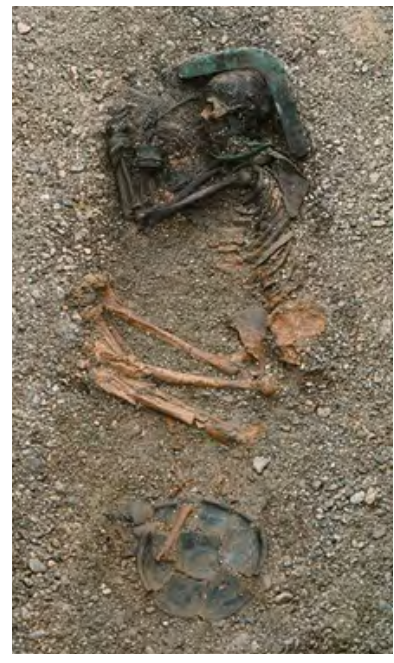

C



Fig. 5. Graves at Franzhausen I. - a. Baden period, Grave 206: a female 45-50 years in the southern part of the grave (head pointing E, face looking N) and a male 50-55 years buried slightly later to the north (head pointing E, face looking S). - b. Early Bronze Age, Grave 126: male 20-25 years, head pointing N, face looking E. - c. Early Bronze Age, Grave 110: female 25-30 years, head pointing S, face looking E. - d. Hallstatt period cremation deposit, Grave 628 (Photos: courtesy of Federal Monuments Authority Austria, Archive Mauerbach).

the observations made by the undertaker Hans Radlherr from Kapelln (Lower Traisen Valley) and reported to Johannes-Wolfgang Neugebauer, in gravel the processes of decay of soft-tissue and wood are faster than in loam. In the Lower Traisen Valley, the partial decay of corpses in gravel takes 3-5 years, whereas in loam it can take 7-8 years. Skeletisation in gravel is reached after ten years, in loam it may take up to 15 years. In gravelly soils, coffins will start to rot after 5-7 years, whereas in loam they can still be fully preserved after 15-20 years. ${ }^{52}$

In the area of the FH I cemetery, gravel, loam, and sand with moderate to high permeability are overlain by a type of black topsoil known as Chernozem..$^{53}$ Unfortunately, no soil profiles from the graves or measurements of the $\mathrm{pH}$-value exist. The types of soil in individual graves can, however, be partially inferred from the descriptions of the grave fills in the archaeological documentation, ${ }^{54}$ by using photographs that show the grave fill and its surroundings before excavation, by drawings that provide codes for grave fills (Fig. 6), and by field photographs of the excavated graves, ${ }^{55}$ which, in some instances, show the type of soil into which the grave was dug (Fig. $7 / \mathrm{a}-\mathrm{c})$.

52 Neugebauer 1991, 116 and Table 22.

53 Neugebauer 1987. - Neugebauer, Neugebauer-Maresch 1988. - See also Österreichische digitale Bodenkarte for the larger region.

54 Neugebauer 1991.

55 See also Fig. 21.

\section{Material and Methods}

In order to determine whether there was post-mortem treatment of the corpses at FH I, a suite of methods was applied to 22 individuals from 22 graves (Fig. 6). The methods consisted of the macroscopic re-examination of the bones, post-hoc archaeothanatological assessment using field photographs, and histotaphonomic analysis. ${ }^{56}$

\subsection{Macroscopic Examination of the Skeletal Material}

Since the purpose of the research was to detect unusual patterns of diagenesis in bone, the 22 skeletons originally examined and published by Karin Wiltschke-Schrotta, Margit Berner and Maria Teschler-Nicola ${ }^{57}$ were re-examined. The bones - with a few minor exceptions - are still in a good general state of preservation. Sex estimation was based on the methods of György Acsádi and János Nemeskéri ${ }^{58}$ and Denise Ferembach, Ilse Schwidetzky, and Milan Stloukal. ${ }^{59}$ Age estimation was based on the methods provided by Gerhard Wolff-Heidegger, Albert Miles, Friedrich Rösing, and

56 The archaeological data and results of the current investigation are summarised in Table 1.

57 Berner 1988. - Teschler-Nicola 1988. - Wiltschke-SchrotTA 1988. - Berner 1992. - BerNer, WiltschKe-SchrotTA 1992. Teschler-Nicola 1992. - Wiltschke-SchrotTa 1992.

58 ACsÁdi, NemesKéri 1970.

59 Ferembach, Schwidetzky, Stloukal 1979. - See also SJøvold $1988,451,458$. 
Denise Ferembach and colleagues. ${ }^{60}$ Description of the teeth follows the notation of the World Dental Federation (FDI = Fédération Dentaire Internationale). Discolouration of the bones was also carefully investigated.

\subsection{Archaeothanatological Investigation}

Archaeothanatology, field anthropology, or anthropologie de terrain is a taphonomically based methodology pioneered by Henri Duday. ${ }^{61}$ The method relies on examination and recording during excavation. ${ }^{62}$ Since in this case, in situ observation during excavation was not possible, we applied a post-hoc analysis as developed by Nathaniel John Harris and Nancy Tayles ${ }^{63}$ for prehistoric graves in Ban Non Wat, Thailand, in order to reconstruct the position of the corpse at the time of the burial. This methodology is based on the use of unpublished field records and photographs as well as published material. ${ }^{64}$ The unpublished documents pertaining to Franzhausen are kept in the archives of the Federal Monument Office in Mauerbach and were made available for this study. The following features of the skeletal position were investigated and used for the analysis: constriction in the shoulders; verticalisation of the clavicles; rotation of the scapulae and the humeri; thoracic volume; anatomical position of rotation of the femora; and position of the pelvis and patellae. ${ }^{65}$ Variations in the posture of the deceased were identified using the flexion of the lower extremities according to parameters provided by Johannes-Wolfgang and Christine Neugebauer (Table 1). ${ }^{66}$

\subsection{Analysis of Bone Alteration and Bioerosion}

\subsubsection{Thin Section Light Microscopy}

Twenty-two samples ${ }^{67}$ were cut from the mid-section of the diaphysis of either the left or right femur (Fig. 8) using a bone saw and then embedded in Biodur (a synthetic resin mixed with E1-hardener at a ratio of 100:28). After hardening, thin sections $100 \mu \mathrm{m}$ thick were cut from these samples,

60 Wolff-Heidegger 1954. - Miles 1963. - Ferembach, SchwiDETZKy, STloukal 1979. - Rösing 1988. - See also Szilvássy 1988, 424.

61 Duday 2009.

62 Boulestin, Duday 2006. - Knüsel 2014, 27.

63 Harris, TAYles 2012.

64 A similar attempt to reconstruct mortuary practices from drawings, field notes, and photographs was made by NiLsson STUTz 2006. 65 A general narrowness of the appearance of the skeleton, and the fact that the limbs are lying close to the body, is not enough to suggest that the body was wrapped: NiLsson STUTz 2006.

66 Neugebauer 1991. - Neugebauer, Neugebauer 1997.

67 The quality of a second thin section from Individual 97 (right femur) was too poor to be included in this study. mounted onto a glass slide using an embedding agent and polished to a thickness between 90 and $50 \mu \mathrm{m}^{68}$ (Fig. 9).

For the histotaphonomic characterisation of diagenetic post-mortem alterations (e.g. microbial bioerosion, collagen loss) in human bones ${ }^{69}$ the 22 histological thin sections were then analysed using a transmitted light microscope (Olympus BX 50) fitted with polarising filters (Fig. 10/a-b). Digital micrographs with 20x, 50x and 100x magnification (Fig. 11) were taken using a digital Olympus camera in conjunction with the microscope.

\subsubsection{Birefringence}

Each bone is composed of a non-organic component (hydroxyapatite) and a smaller organic component including type I collagen (a large protein molecule that makes up $90 \%$ of the organic phase), non-collagenous proteins, lipids, and water. The proportions of these components vary with age and health. ${ }^{70}$ Type I collagen forms long thin fibrils, which are packed side-by-side in parallel bundles, the so-called collagen fibres. ${ }^{71} \mathrm{~A}$ bed of parallel collagen fibres constitutes a lamella; several lamellae are organised in concentric rings around the so-called Haversian canal, in which the bone's blood supplies, nerves, connective tissue and lymphatic vessels are located. Fibres in successive lamellae are orientated in different directions, which adds strength to the structure. The entire structure, which is marked by a cement line on the outer side, forms one Haversian system or secondary osteon. The secondary osteons, which are products of bone remodelling, increase in number with age and are an essential part of the cortical bone structural organisation in an adult human. ${ }^{72}$

Through the application of transmitted light microscopy, using polarised light, the orientation of the collagen fibres can be identified through the microscope. An auxiliary element, a first-order red retardation plate (quartz), was used to assess the birefringence of successive lamellae: collagen fibres oriented transversely to the light beam appear yellow and collagen fibres oriented approximately in the direction of the light appear blue (Fig. 10/b). ${ }^{73}$ This results in a shape similar to a Maltese cross within the osteon; this is called a Brewster cross (Fig. 12) ${ }^{74}$

68 Novotny et al. 2003.

69 E.g. Hacketт 1981. - Child 1995. - Jackes et al. 2001. - White, Воотн 2014.

70 Boskey 2013.

71 VAN DER REST 1991.

72 White, Folkens 2005, 42-43. - White, Black, Folkens 2005, 35-37. - Воотн 2017, 7-9.

73 SCHultz 1997.

74 Turner-Walker, Mays 2008. 


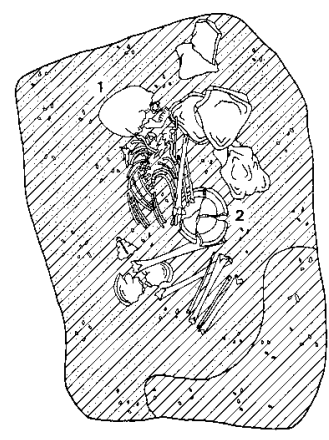

4

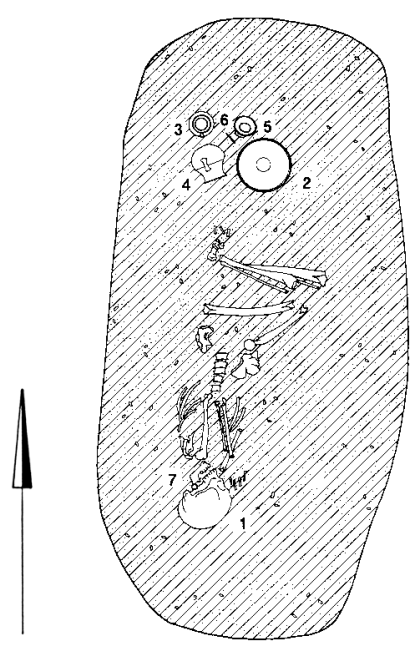

37
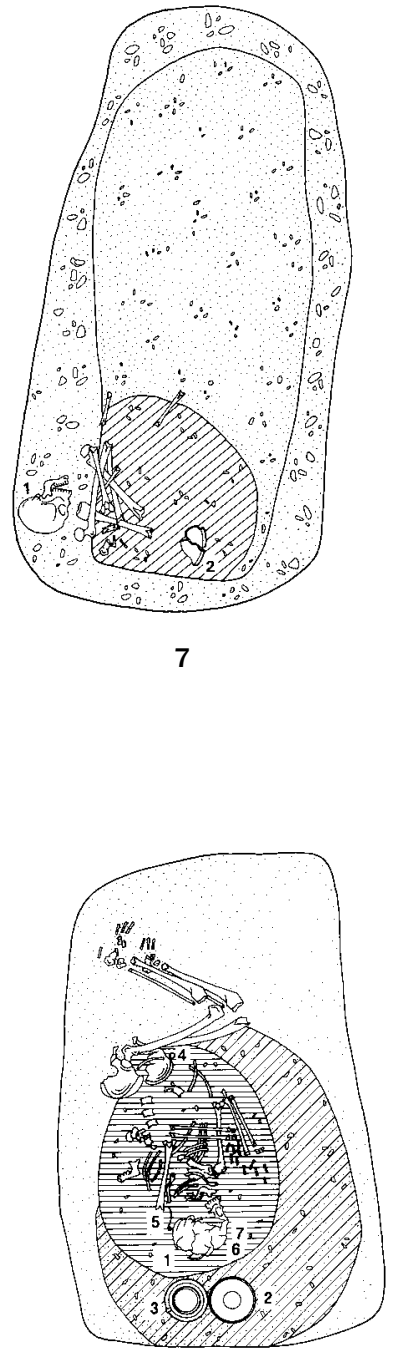

46

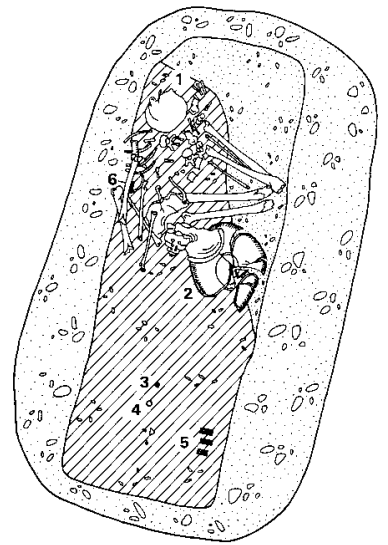

8

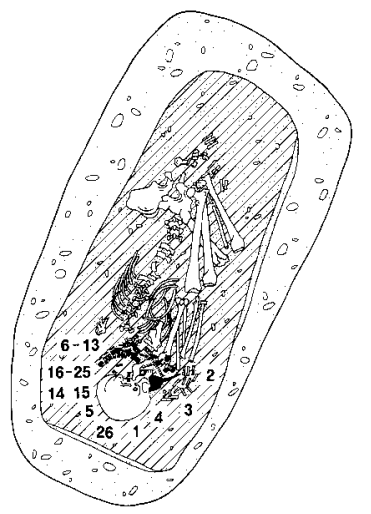

97

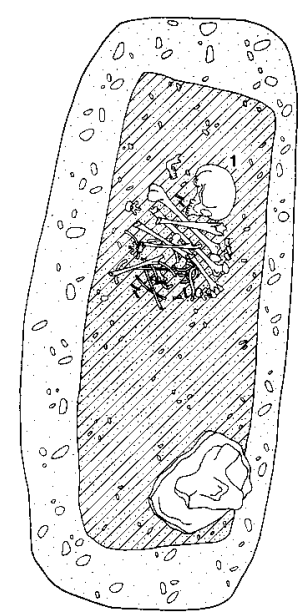

28

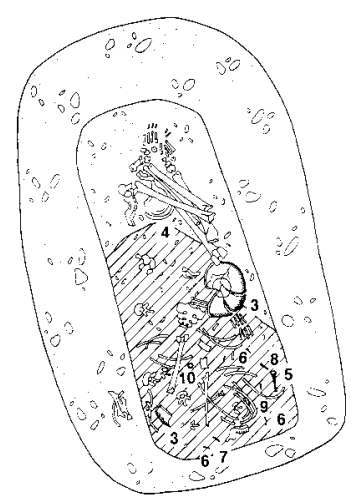

104

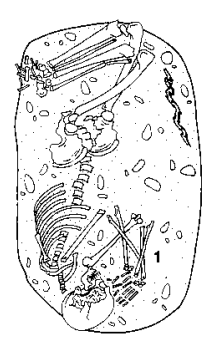

113

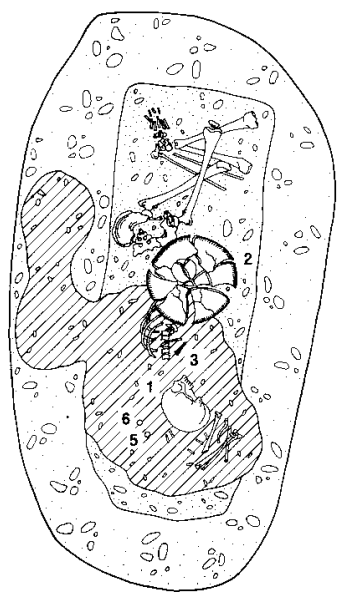

220

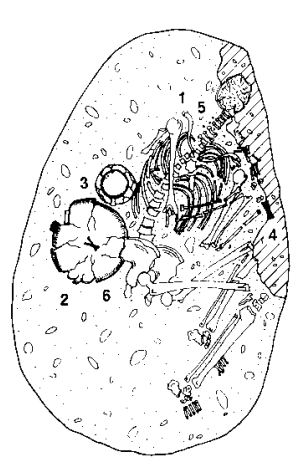

230

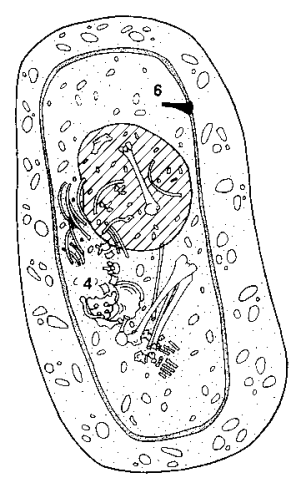

241

Fig. 6. Drawings of the 22 graves and skeletons that were selected for analysis (Neugebauer, NeugEbauer 1997, Vol. 2). 


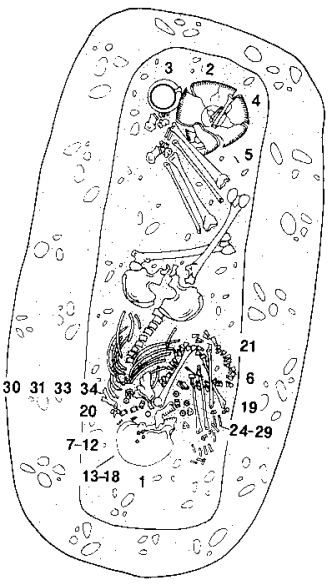

283



310

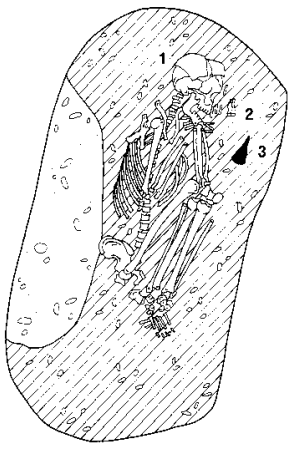

347

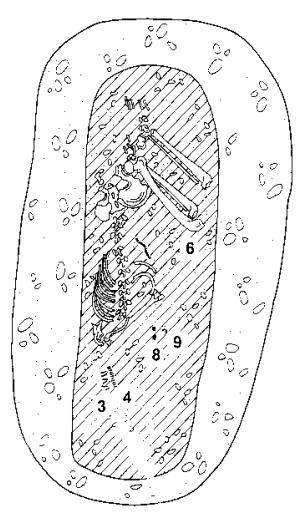

434

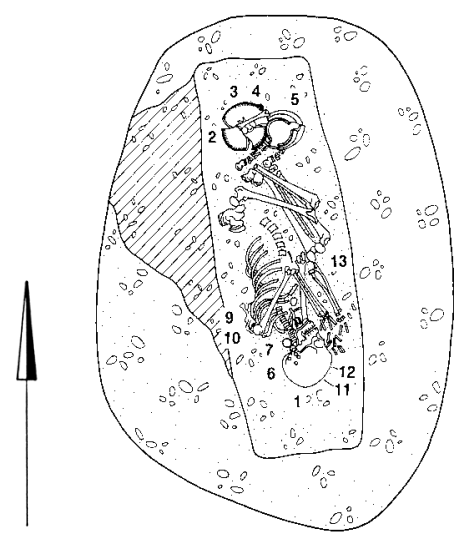

491
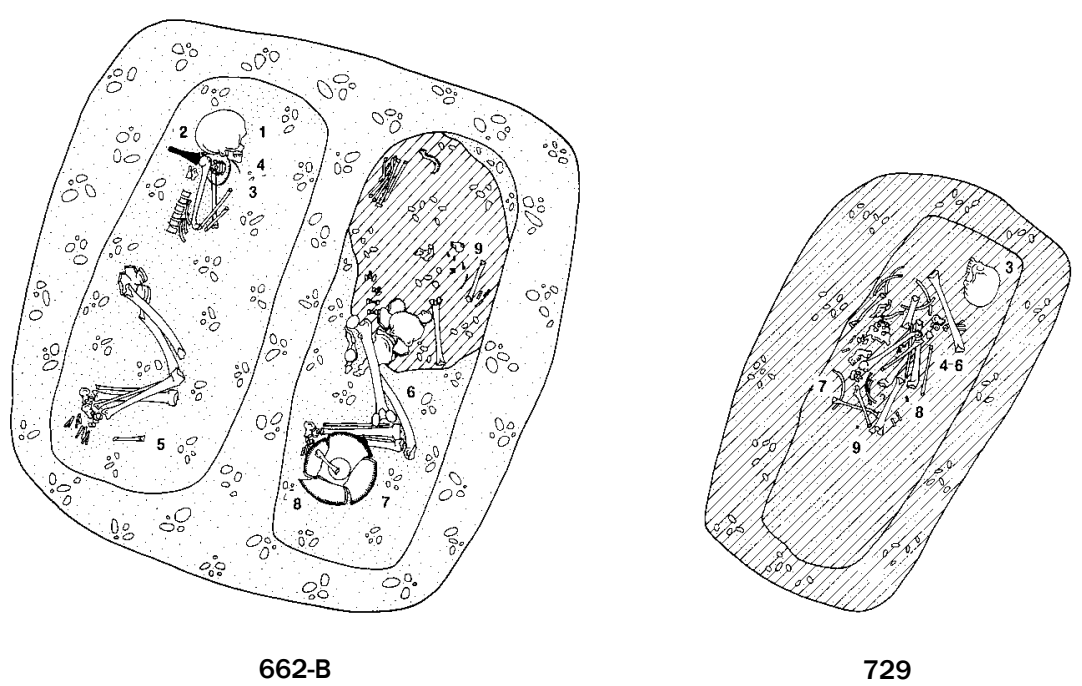

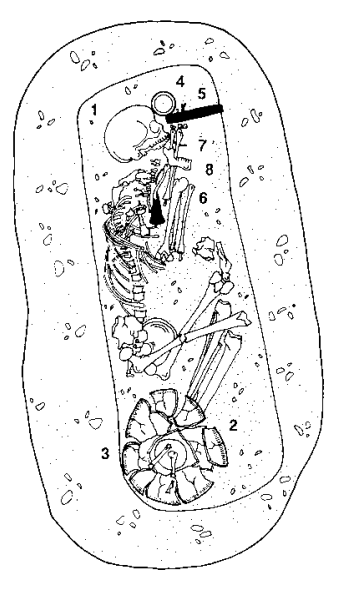

840-1
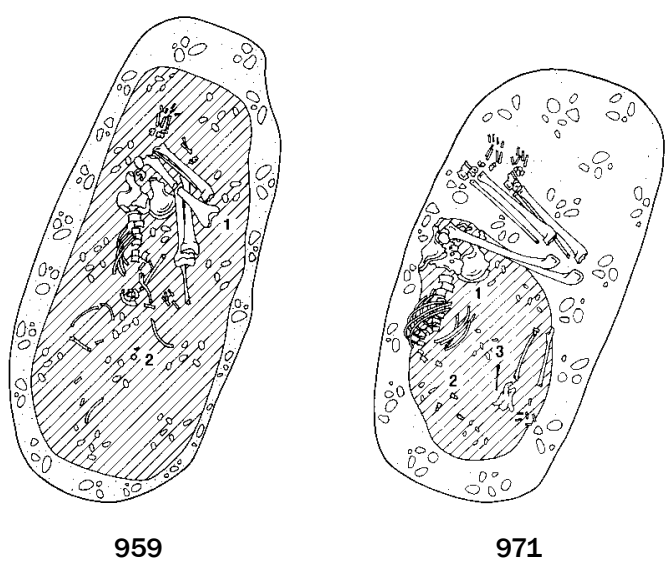

971

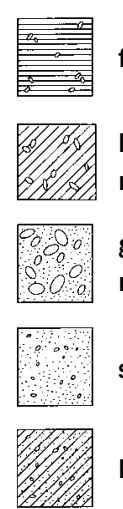

fine humus-rich material

humus-rich, partly gravelly

material

gravelly, slightly humus-rich material

sandy, slightly gravelly material

loamy, slightly gravelly material 
Table 1. Franzhausen I. Archaeological data (based on Neugebauer, Neugebauer 1997) and results of macroscopic and microscopic bone analyses. The depth of the grave is measured from the upper surface of the modern topsoil. Abbreviations: $\mathrm{N}=$ north, $\mathrm{S}=$ south, $\mathrm{l}=$ lamellate, $\mathrm{b}=$ budded, $11=$ linear-longitudinal.

\begin{tabular}{|c|c|c|c|c|c|c|c|c|c|c|}
\hline $\begin{array}{l}\text { Grave } \\
\text { no. }\end{array}$ & $\begin{array}{l}\text { Depth } \\
\text { in } \mathrm{cm}\end{array}$ & Coffin & Sex & Head & $\begin{array}{c}\text { Lateral } \\
\text { position }\end{array}$ & $\begin{array}{l}\text { Flexion } \\
\text { of legs }\end{array}$ & $\begin{array}{c}\text { Degree of } \\
\text { disturbance* }\end{array}$ & $\begin{array}{l}\text { Skeletisation } \\
\text { during } \\
\text { disturbance* }\end{array}$ & Metal grave goods & $\begin{array}{c}\text { Skeletal } \\
\text { discolouration }\end{array}$ \\
\hline 4 & 100 & $?$ & male & $\mathrm{N}$ & left & moderate & partial & complete & - & - \\
\hline 7 & 242 & yes & female & $?$ & $?$ & $?$ & unknown & complete & Noppenring (gold) & intense \\
\hline 8 & 196 & yes & female & $?$ & right & moderate & partial & complete & $\begin{array}{l}\text { Noppenring, Spiralröll- } \\
\text { chen, dress elements }\end{array}$ & intense \\
\hline 28 & 163 & yes & male & $?$ & $?$ & $?$ & unknown & complete & - & intense \\
\hline 37 & 110 & $?$ & female & $S$ & right & loose & slight & $\begin{array}{c}\text { not yet } \\
\text { complete? }\end{array}$ & awl, spiral ring fragment & slight \\
\hline 46 & 99 & - & female & $S$ & right & loose & slight & complete & $\begin{array}{l}\text { Rollenkopfnadel, Nop- } \\
\text { penringe }\end{array}$ & slight \\
\hline 97 & 140 & yes & female & $S$ & right & tight & none? & complete? & $\begin{array}{l}\text { Scheibenkopfnadel, Spi- } \\
\text { ralröllchen necklace, Nop- } \\
\text { penringe, dress elements }\end{array}$ & intense \\
\hline 104 & 150 & yes & female & $S$ & right & tight & partial & complete & $\begin{array}{l}\text { Spiraltutulus, piece of } \\
\text { sheet metal }\end{array}$ & slight \\
\hline 113 & 102 & - & female & $S$ & right & loose & none & & - & - \\
\hline 220 & 90 & yes & female & $S$ & right & loose & partial & $\begin{array}{c}\text { not yet } \\
\text { complete? }\end{array}$ & Noppenringe & slight \\
\hline 230 & 118 & - & male & $\mathrm{N}$ & left & moderate & none & & wire rings & - \\
\hline 241 & 177 & yes & male & $\mathrm{N}$ & left & tight & partial & complete & flanged axe & intense \\
\hline 283 & 229 & yes & female & $S$ & right & loose & slight & $\begin{array}{c}\text { not yet } \\
\text { complete? }\end{array}$ & $\begin{array}{l}\text { awl, Hülsenkopfnadel, } \\
\text { Noppenringe, Spiralröll- } \\
\text { chen necklace, Blechröll- } \\
\text { chen, dress ornaments }\end{array}$ & intense \\
\hline 310 & 161 & yes & male & $\mathrm{N}$ & left & moderate & slight & complete? & - & - \\
\hline 347 & 87 & - & male & $\mathrm{N}$ & left & tight & none & & dagger & - \\
\hline 434 & 181 & yes & female & $S$ & right & moderate & partial & complete? & $\begin{array}{l}\text { Blechröllchen, awl, Spi- } \\
\text { ralröllchen, beads, sheet } \\
\text { metal fragment, Noppen- } \\
\text { ring fragment }\end{array}$ & intense \\
\hline 491 & 218 & yes & female & $S$ & right & tight & none? & & $\begin{array}{l}\text { Noppenringe, Rollenkopf- } \\
\text { nadel }\end{array}$ & intense \\
\hline $662-\mathrm{B}$ & 218 & yes & male & $\mathrm{N}$ & left & loose & partial & complete & Blechkopfnadel & - \\
\hline 729 & 151 & yes & female & $?$ & $?$ & $?$ & mostly & complete & $\begin{array}{l}\text { awl, beads, ring fragments, } \\
\text { Spiralröllchen fragments }\end{array}$ & slight \\
\hline $840-1$ & 225 & yes & male & $\mathrm{N}$ & left & moderate & slight & complete? & $\begin{array}{l}\text { dagger, arm ring fragment, } \\
\text { Scbleifenkopfnadel, Nop- } \\
\text { penringe }\end{array}$ & intense \\
\hline 959 & 138 & yes & female & $?$ & right & tight & partial & complete & Spiralröllchen, Noppenring & slight \\
\hline 971 & 140 & $?$ & female & $S$ & right & moderate & partial & complete & - & slight \\
\hline
\end{tabular}

*Assessment according to Neugebauer, Neugebauer 1997.

* Discolouration of the bones is partial and varies in intensity.

$\because \%$ Visible osteons : collagen traces : remainder [damaged areas, assessment not possible]. 


\begin{tabular}{|c|c|c|c|c|c|c|c|c|c|c|}
\hline $\begin{array}{l}\text { Grave } \\
\text { no. }\end{array}$ & $\begin{array}{c}\text { Femur } \\
\text { sampled }\end{array}$ & $\begin{array}{c}\text { Femur } \\
\text { discolouration } * *\end{array}$ & $\begin{array}{c}\text { Thin } \\
\text { section } \\
\mu \mathrm{m}\end{array}$ & $\begin{array}{l}\text { Histological } \\
\text { preservation }\end{array}$ & $\begin{array}{c}\mathrm{OH} \\
\text { Index }\end{array}$ & $\begin{array}{l}\text { Non-Wedl } \\
\text { MFD }\end{array}$ & $\begin{array}{c}\text { Wedl } \\
\text { tunnels }\end{array}$ & Lacunae & $\begin{array}{l}\text { Collagen } \\
\text { count } * * * \%\end{array}$ & $\begin{array}{c}\text { Collagen } \\
\%\end{array}$ \\
\hline 4 & right & - & 60 & III & 1 & $1, b, 11$ & present & present & $0: 74: 226$ & 0.25 \\
\hline 7 & left & intense green, brown & 90 & $\mathrm{I}$ & 2 & - & - & - & $246: 54: 0$ & 5.05 \\
\hline 8 & left & intense green & 70 & $\mathrm{I}$ & 2 & - & - & - & $106: 184: 0[10]$ & 6.99 \\
\hline 28 & left & slight green & 60 & III & 0 & $1, b$ & present & present & $0: 205: 95$ & 1.30 \\
\hline 37 & left & - & 60 & IV & 0 & $1, b, 11$ & present & present & $0: 79: 209[12]$ & 0.36 \\
\hline 46 & left & - & 60 & III & 1 & $\mathrm{~b}, 11$ & present & present & $0: 159: 141$ & 0.54 \\
\hline 97 & left & slight green & 50 & III & 2 & $1, b$ & - & present & $0: 242: 58$ & 2.60 \\
\hline 104 & right & brown & 60 & III & 1 & $1, b, 11$ & present & present & $0: 168: 132$ & 1.09 \\
\hline 113 & right & - & 60 & III & 0 & $1, b, 11$ & present & present & $0: 198: 102$ & 0.42 \\
\hline 220 & right & - & 50 & III & 1 & $1, b, 11$ & - & present & $0: 229: 71$ & 1.44 \\
\hline 230 & left & - & 50 & III & 0 & $1, b$ & - & present & $0: 62: 238$ & 0.80 \\
\hline 241 & left & - & 50 & III & 1 & $1, b, 11$ & - & present & $0: 162: 138$ & 1.68 \\
\hline 283 & right & - & 60 & III & 0 & $1, \mathrm{~b}$ & - & present & $0: 64: 236$ & 0.74 \\
\hline 310 & left & - & 70 & III & 1 & $1, \mathrm{~b}$ & - & present & $0: 185: 115$ & 0.53 \\
\hline 347 & right & - & 70 & III & 1 & $1, b, 11$ & present & present & $0: 23: 277$ & 0.47 \\
\hline 434 & right & brown & 70 & III & 1 & $1, b, 11$ & - & present & $2: 130: 168$ & 1.26 \\
\hline 491 & right & brown & 70 & IV & 1 & $1, b$ & - & present & $0: 80: 202[18]$ & 1.09 \\
\hline $662-\mathrm{B}$ & right & brown & 70 & III & 1 & $1, b$ & - & present & $0: 158: 142$ & 0.37 \\
\hline 729 & right & - & 70 & IV & 1 & $1, b, 11$ & - & present & $0: 148: 152$ & 0.71 \\
\hline $840-1$ & left & intense green, brown & 50 & I & 3 & - & - & - & $54: 245: 1$ & 5.13 \\
\hline 959 & right & brown & 60 & III & 2 & $1, b, 11$ & - & present & $0: 247: 53$ & 1.13 \\
\hline 971 & right & intense green, brown & 50 & I & 3 & - & - & - & $20: 276: 4$ & 5.44 \\
\hline
\end{tabular}




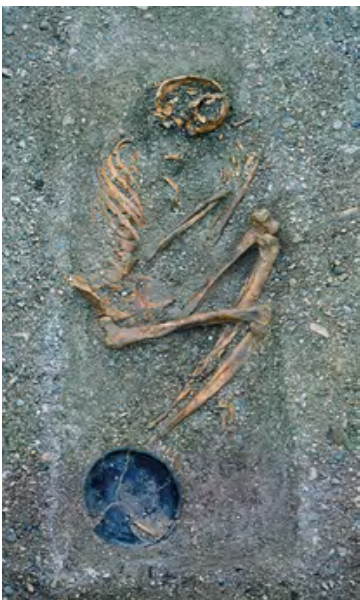

a

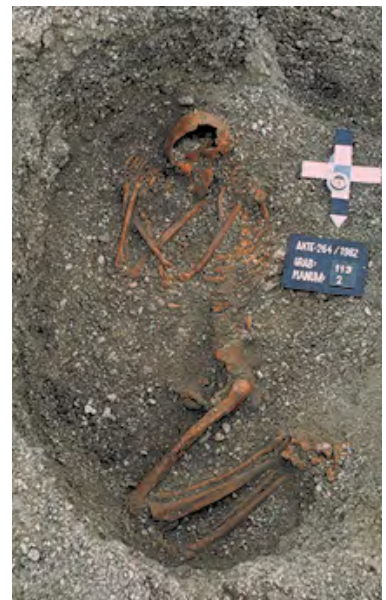

b



Fig. 7. Types of soil at Franzhausen I. - a. Grave 310 (gravel, coffin burial, body undisturbed). - b. Grave 113 (gravel, no coffin, body undisturbed). - c. Grave 37 (loam, coffin?, body slightly disturbed) (Photos: courtesy of Federal Monuments Authority Austria, Archive Mauerbach).

\subsubsection{Bioerosion}

Bioerosion in bone can be described as a combination of physical taphonomic and diagenetic processes ${ }^{75}$ leading to alteration. Alteration is caused by different biological, physical, or chemical factors. ${ }^{76}$ Caused by microorganisms, bone alteration has an influence on both the surface and the microstructure of the bone. This results in the well-known fragility of archaeological bone and also affects chemical and radiological analyses. ${ }^{77}$ While physical factors are limited to mechanical destruction, chemical and biological factors cause a transformation within the microstructure of the bone. ${ }^{78}$ Histotaphonomic analysis of diagenetic modifications of bone microstructure under transmitted light

75 Turner-Walker, Mays 2008

76 Piepenbrink 1986.

77 Turner-Walker, Mays 2008.

78 Turner-Walker, Mays 2008. microscopy reveals if this alteration is caused by bacteria or by fungi. ${ }^{79}$

The most common form of diagenesis found in human bone from archaeological contexts is produced by the organism's intestinal microbiota invading the bone through the Haversian canals (Fig. 12) during the early stages of putrefaction. These enteric putrefactive bacteria are the prime cause of the characteristic internal bone bioerosion. ${ }^{80}$ Decay leads to a microscopic focal destruction (MFD) wherein the microstructure of the bone becomes tunnelled through by the endogenous bacteria from the intestinal tract. ${ }^{81}$ Cecil Hackett has provided further characterisation of the microbial attack by defining three types of bacterial microscopic focal destruction, which are lamellate, budded, and linear-longitudinal (Fig. 13). ${ }^{82}$

An absence or low occurrence of bacterial attack suggests that the mechanism of natural decay of the body-tissue was stopped or decelerated by natural or artificial means. If the presence of bactericidal elements such as copper can be excluded, ${ }^{83}$ it becomes evident that some form of natural or artificial mummification has taken place in an early post-mortem stage. ${ }^{84}$

While bacterial attacks create so-called non-Wedl MFD, Wedl tunnelling (Wedl MFD) ${ }^{85}$ refers to fungi. It has been suggested that Wedl tunnelling might be associated with bone lying in an open environment for an extended period of time. ${ }^{86}$

Alteration caused by bioerosion can be seen within the thin section as extensive dark stained areas. This is caused by infiltration of exogenous substances and staining of the lacunae. Lacunae are small cavities between the concentric rings of the lamellae which contain the osteocytes and are connected to each other by small canals (canaliculi). Viewed by transmitted light microscopy the osteocyte lacunae

79 Jans et al. 2004.

80 Yoshino et al. 1991. - Bell, Skinner, Jones 1996. - Jans et al. 2004. - White, Bоотн 2014. - Booth 2017, 12.

81 White, Booth 2014. - Booth, Chamberlain, Parker Pearson 2015. - Воотн 2016.

82 Наскетт 1981. - Воотн 2017, 10.

83 Assis et al. 2015

84 Janaway 1987. - Janaway 1996. - Mant 1987. - Yamada, Kudou, Takahashi-Iwanaga 1990. - Booth, Chamberlain, Parker PearSON 2015. - ВоOTH 2016.

85 Named after Carl Wedl, who first presented the results of his research on 14 July 1864 during a meeting of the Austrian Academy of Sciences' Section for Mathematics and Natural Sciences. The study was published in the following year: Wedl 1865. - Marchiafava, BonucCi, Ascenzi 1974. - HACKeTt 1981.

86 JANS et al. 2004, 91. - BоOth, MAdGwick 2016, 21. - BRÖNNImann, Portmann, Pichler 2017. 


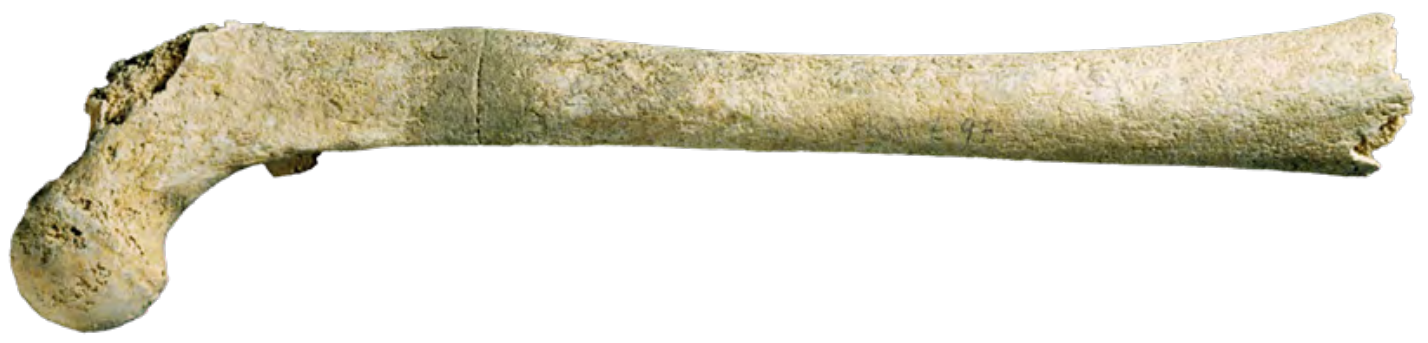

Fig. 8. Anterior view of left femur from Grave 97 with proximal end towards the left (Photo: F. Novotny).
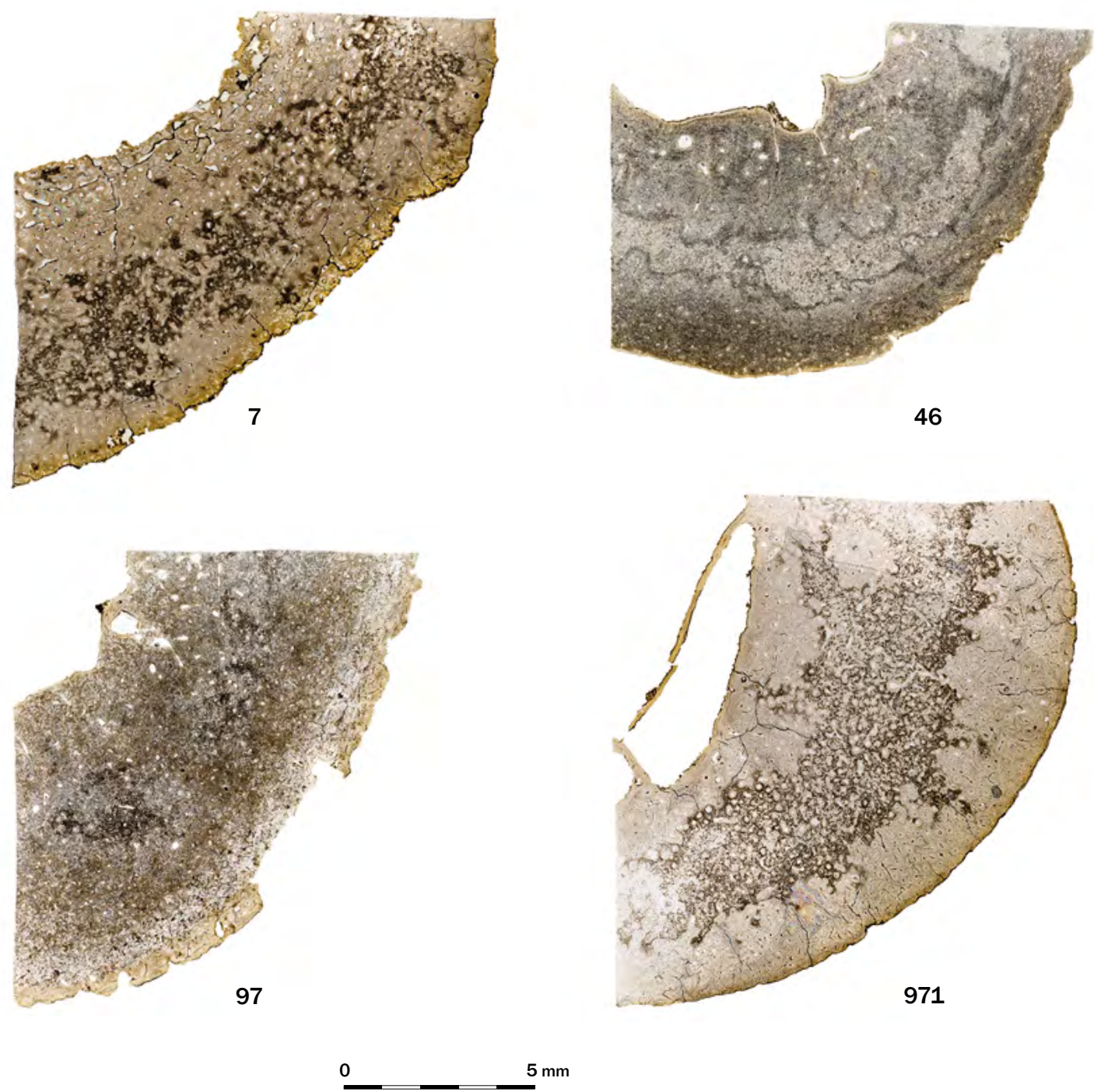

Fig. 9. Glass slides of thin sections (femora 7, 46, 97 and 971), showing variation in the degree of bioerosion (Photos: W. Reichmann, (C) NHM Vienna). 


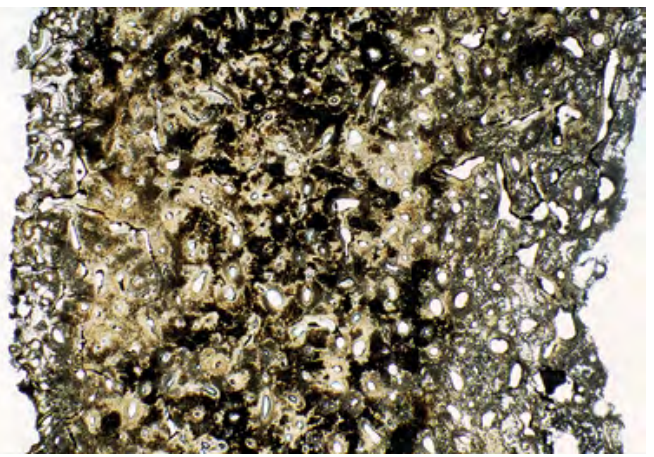

a

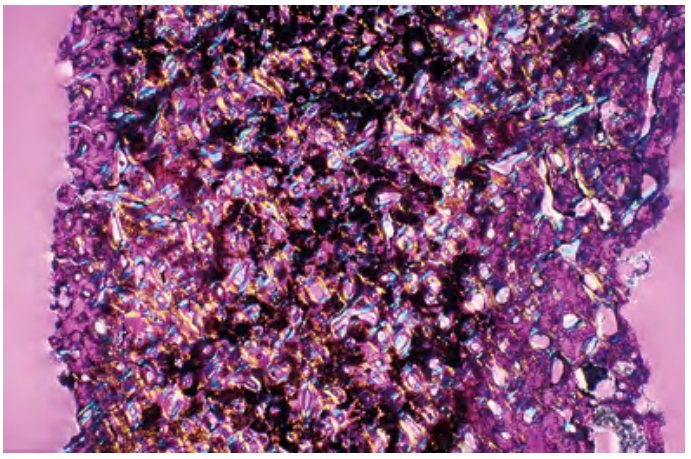

b

Fig. 10. Microscopic view of thin section (Femur 7). - a. Under plain light. - b. Under polarised light using a first-order red plate (Photos: F. Novotny).

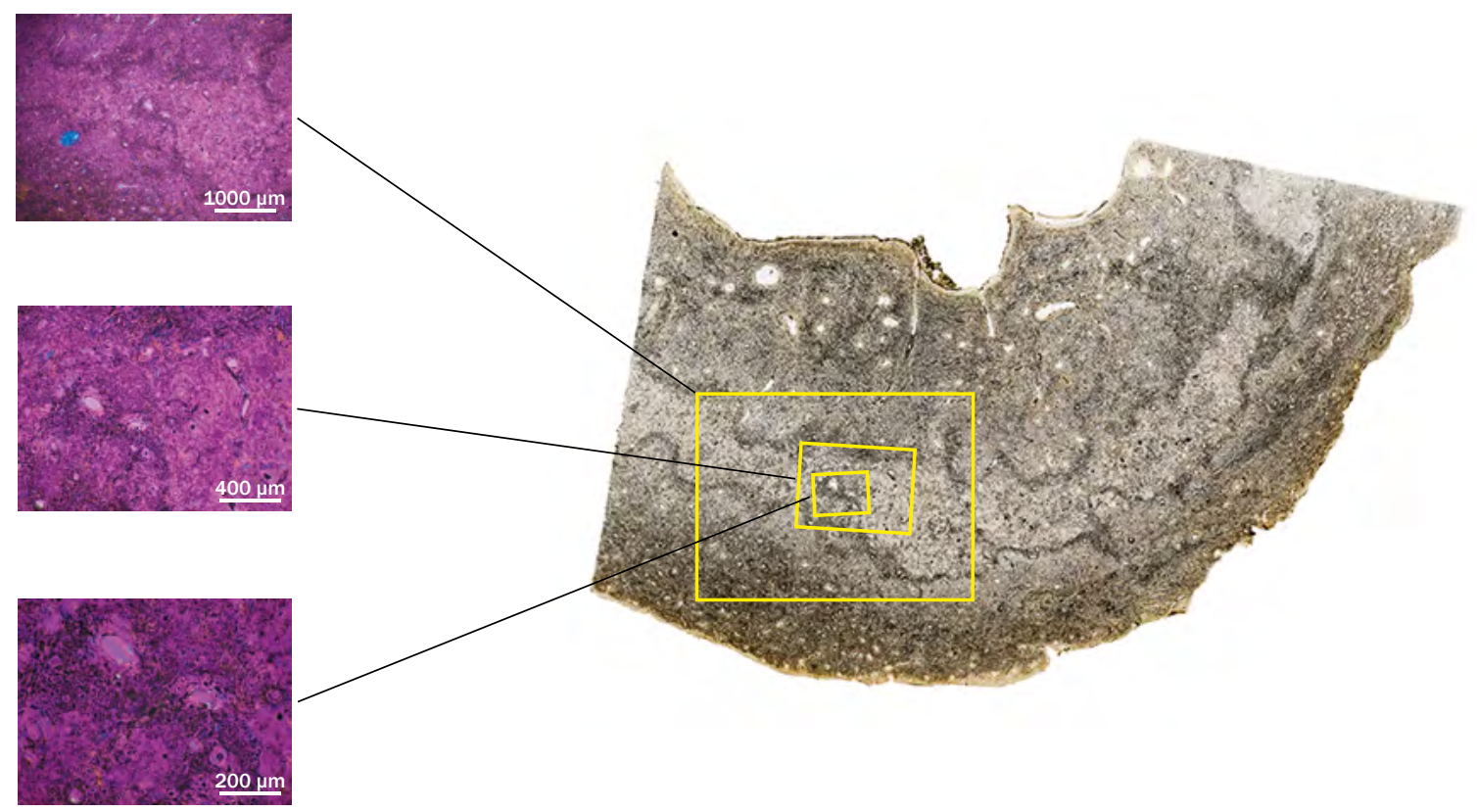

Fig. 11. Thin section of a femur midshaft cortical bone segment (Grave 46). Selected areas (framed in yellow) show structural changes in 20x, 50x, and 100x magnification (left) (Photo of thin section: W. Reichmann, ( NHM Vienna; micrographs: K. Mandl; graphics: E. Weiss-Krejci).

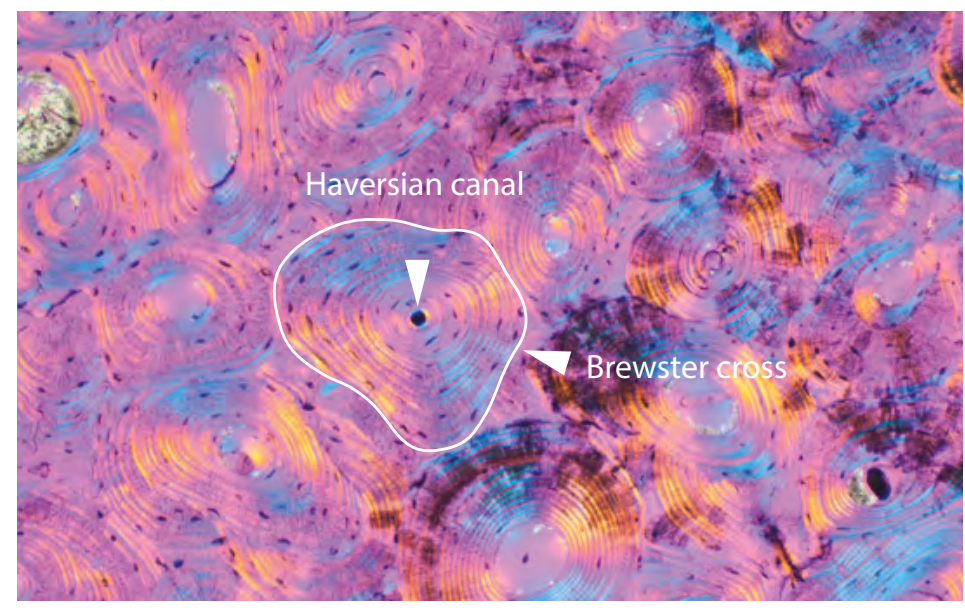

Fig. 12. Bone histology/microstructure of an adult human (thin section detail, femur Grave 971). The Haversian canal is in the centre of the osteon; viewed under polarised light using a first-order red plate, the collagen fibres can be recognised as yellow and blue coloured Brewster crosses (Photo and graphics: K. Mandl). 


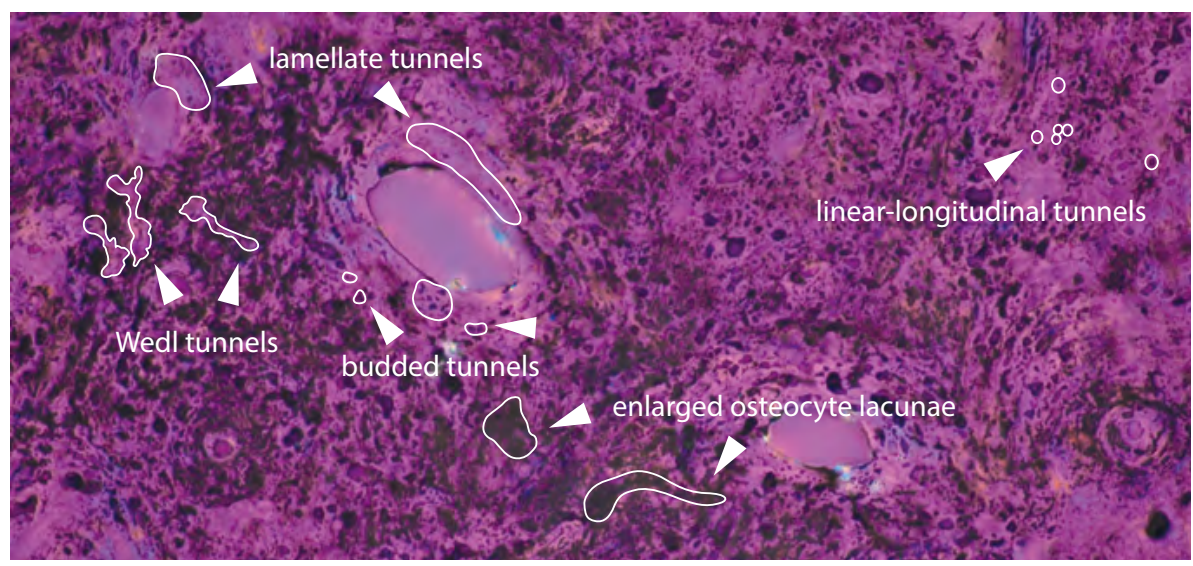

Fig. 13. Microscopic focal destruction (MFD) as form of bioerosion in bone (thin section detail, femur Grave 46). The microstructure has been tunnelled by invading microorganisms: microbial attack is caused by fungi (Wedl MFD) as well as bacteria (lamellate, budded, and linear-longitudinal non-Wedl MFD). Enlarged osteocyte lacunae result from infiltration and staining during diagenesis (Photo and graphics: K. Mandl).

appear as little dark spots (see Fig. 12). During diagenesis the lacunae become enlarged as a result of infiltration and staining ${ }^{87}$ and appear as amalgamated dark areas (Fig. 13).

\subsubsection{Assessment of Birefringence and Bioerosion}

When considering Holocene archaeological bone, four distinct states of preservation can be defined. ${ }^{88}$ Type I describes bones with good histological maintenance and high collagen weight. Type II, the so-called Apigliano style, shows poor collagen content caused by an accelerated collagen hydrolysis but an unchanged microstructure. The mineral component of the bone matrix appears recrystallised. Type III refers to bones with poor histological collagen preservation and microstructure, caused by bacterial attack. Type IV can - but doesn't have to - show bacterial modification. The collagen content is low and the mineral component is dissolved. ${ }^{89}$

Diagenetic bone alteration can also be assessed using the Oxford Histological Index (OHI) developed by Robert Hedges, Andrew Millard, and Alistair Pike. ${ }^{90}$ The OHI describes the level of the altered bone microstructure by applying an ordinal scale ranging from 0 (worst preserved only a few regions of the bone microstructure are unaltered) to 5 (best preserved - bone microstructure is unchanged and conforms to that of fresh bone).

87 Gordon, Buikstra 1981. - Garland 1987. - Bell, Skinner, Jones 1996. - Turner-Walker, Peacock 2008. - White, Booth 2014. - Booth, Chamberlain, Parker Pearson 2015.

88 SмiтH et al. 2007.

89 Grupe, Harbeck, McGlynn 2015, 169-170.

90 Hedges, Millard, Pike 1995.
A disadvantage of both methods is that the analysis of thin sections is limited to a selected area of the bone and therefore does not reflect the total bone composition. Individual bone compartments can corrode differently, ${ }^{91}$ leading to different assessments of value. Furthermore, both are intuitive analyses. Nevertheless, several studies ${ }^{92}$ have shown that the $\mathrm{OHI}$ is an effective way to describe the decomposition and preservation of bone microstructure.

One aim of the present study was to identify various levels of bioerosion within the sample of skeletons not only by the use of the OHI but by quantifying the remaining collagen within the thin section. Two methods of thin-section analysis were employed. For the quantification of the microstructural features of the histological thin sections an image analysis software package, KS 300 (with a computerised image analysis technique), from ZEISS was used. This programme evaluates the proportion of collagenous structures, which are seen as blue and yellow collagenous fibres, as well as post-mortem destruction by microorganisms (microbial bioerosion) seen as black dots or black coloured areas. For this analysis the thin sections were divided into an external, medial, and internal section and each section was measured three times. At the end of the process an average value of all the measurements pertaining to the collagenous post-mortem destruction for each histological thin section was produced $^{93}$ (see Table 1).

91 Grupe, Harbeck, McGlynn 2015, 167, 169.

92 Otтoni et al. 2009. - Deviese et al. 2010. - Sosa et al. 2013.

93 Novotny et al. 2003. 




a

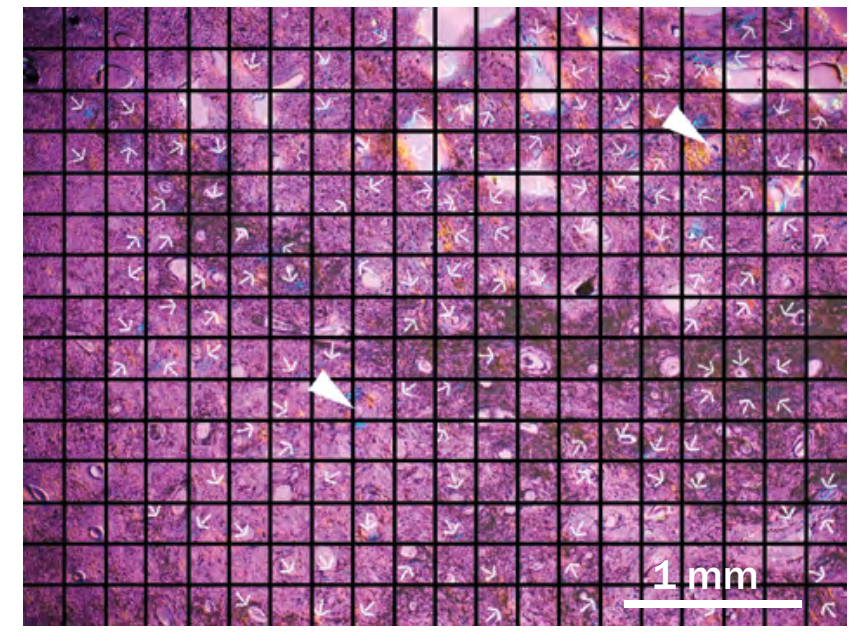

b

Fig. 14. Femur thin section 434 under polarised light. - a. Micrograph covering c. $15 \mathrm{~mm}^{2}$. - b. Micrograph covering c. 15 mm ${ }^{2}$ divided into 300 quadrants $(20 \times 15)$. The collagen count produced a value of $2: 130: 168$ (two visible osteons [large white arrows] : 130 quadrants with visible clusters of osteon remains [small white arrows] : a remainder of 168) (Photos and graphics: K. Mandl).

An additional method to determine the quantity of collagen remaining within the thin section was developed. This method, which was inspired by methods from histomorphometry, ${ }^{94}$ produces a tripartite value. For this, $20 \times$ magnified micrographs covering an area of c. $15 \mathrm{~mm}^{2}(4.4 \times$ $3.3 \mathrm{~mm}$ ) (Fig. 14/a) were subdivided into $20 \times 15$ quadrants (= 300 quadrants) (Fig. 14/b). All the areas in which collagen was preserved were marked and a distinction was made between the assessment of collagen (osteons) (Fig. 14/b, large arrows) and recognisable collagen (visible clusters of collagen within a quadrant) (Fig. 14/b, small arrows). Each osteon was only counted once, whereas recognisable collagen was counted by quadrant; e.g. the thin section of the femur from Grave 434 produced a value of $2: 130: 168$ in 300 quadrants because there are two osteons, 130 quadrants with visible clusters and a remainder of 168 (Fig. 14/b and Table 1).

\section{Results}

The results of macroscopic examination and the summary of the histotaphonomic analysis are presented in Table 1.

\subsection{Results of Macroscopic Skeletal Examination}

The 22 individuals in the sample had been previously identified as ten males and twelve females. ${ }^{95}$ In the course of this

94 Kerley 1965. - Kerley, Ubelaker 1978. - MaAt et al. 2006. 95 Berner, Wiltschke-Schrotta 1992, Table 1. - The individual in 662-B was published as a female by WiltschKe-SCHrotTA 1988 and Neugebauer, Neugebauer 1997 but according to Berner, WiltschKe-SchrotTA 1992 and our investigation, it is a male. investigation, the sex of the individuals from graves 7 and 46 was corrected to female (Table 2) so the sample finally consisted of eight males and fourteen females with the result that all the individuals whose burial position could be determined without doubt followed a gendered body orientation (Table 1). Regarding the estimation of age, a few minor changes to the results from previous studies were made, but the broad age groups remained more or less the same. ${ }^{96}$ The current study identified eleven adult, seven adult-mature, three mature, and one mature-senile individuals (Table 2). ${ }^{97}$

A dental examination of the skeletons from $\mathrm{FH}$ I had already been completed by Wiltschke-Schrotta and revealed the frequency of dental caries to be $37.1 \%$ in the permanent teeth of 381 individuals and $26.9 \%$ in the entire sample (deciduous and permanent teeth pertaining to 554 individuals). ${ }^{98}$ Since no individual data about caries and abscesses had hitherto been published for FH I, dental records including caries, calculus deposition and tooth loss for the 22 re-examined individuals were added to Table 2.

96 According to WiltschKe-SChrotTA 1988 and BeRner, Wiltschке-SснRоTTA 1992, the 22 individuals comprise of eleven adult, seven adult-mature, one mature, and three mature-senile individuals. 97 Deviations from earlier study: Grave 97: adult 20-30 years; graves 4 and 113: adults 20-35 years; graves 46 and 283: adults 2535 years; graves 37, 220, 729, 959, and 971: adult-mature individuals of 30-45 years; graves 28 and 434: mature adults 45-60 years. - Wiltschke-Schrotta 1988 and Berner, Wiltschke-Schrotta 1992, Table 1: Grave 97: 20-25 years; Grave 4: 20-30 years; Grave 283: 25-30 years; graves 113 and 220: 30-40 years; graves 37, 46, 729, 959, and 971: 35-45 years; and graves 28 and 434: 50-70 years. 98 WiltschKe-SchrotTa 1988, 314. 
Table 2. Franzhausen I. Anthropological data (based on re-analysis).

\begin{tabular}{|c|c|c|c|c|c|}
\hline $\begin{array}{l}\text { Grave } \\
\text { no. }\end{array}$ & $\begin{array}{l}\text { Inv. no. } \\
\text { (NHM) }\end{array}$ & Sex & Age & $\begin{array}{l}\text { Dental record } \\
\text { (FDI-notation) }\end{array}$ & Pathologies \\
\hline 4 & 23614 & male & adult (20-35) & none & none described \\
\hline 7 & 23617 & female & adult-mature $(35-50)$ & no statement possible & none described \\
\hline 8 & 23618 & female & mature-senile (50-70) & $\begin{array}{l}\text { caries on molars }(37,38) \text { and } \\
\text { abscess }(36)\end{array}$ & abscess \\
\hline 28 & 23634 & male & mature $(45-60)$ & $\begin{array}{l}\text { calculus on incisors }(31,32,41,42) \\
\text { and canines }(33,43)\end{array}$ & none described \\
\hline 37 & 23641 & female & adult-mature (30-45) & $\begin{array}{l}\text { caries on molars }(37,47) \text {, calculus } \\
\text { on canine }(33) \text {, premolars }(34,35) \text {, } \\
\text { and molar }(47)\end{array}$ & none described \\
\hline 46 & 23649 & female & adult (25-35) & $\begin{array}{l}\text { calculus on incisor (32) and } \\
\text { premolar (34) }\end{array}$ & none described \\
\hline 97 & 23683 & female & adult $(20-30)$ & none & none described \\
\hline 104 & 23693 & female & adult (20-25) & none & bone augmentation \\
\hline 113 & 23700 & female & adult (20-35) & caries on molars $(17,28,37)$ & none described \\
\hline 220 & 23784 & female & adult-mature (30-45) & none & none described \\
\hline 230 & 23790 & male & adult (25-35) & no statement possible & none described \\
\hline 241 & 23801 & male & adult (20-25) & none & none described \\
\hline 283 & 23837 & female & adult (25-35) & none & $\begin{array}{l}\text { cribra cranii, sinusitis, periodontal } \\
\text { disease, remodelled periostitis }\end{array}$ \\
\hline 310 & 23858 & male & mature $(40-60)$ & $\begin{array}{l}\text { caries on molar }(38) \text { and calculus } \\
\text { on entire dentition }\end{array}$ & $\begin{array}{l}\text { healed blunt force trauma; depression } \\
\text { fracture of Os frontale; } \\
\text { moderate osteophytosis }\end{array}$ \\
\hline 347 & 23892 & male & adult-mature $(30-50)$ & none & cribra cranii \\
\hline 434 & 23959 & female & mature (45-60) & no statement possible & arthrosis \\
\hline 491 & 24006 & female & adult (20-25) & caries on molar (47) & none described \\
\hline $662-B$ & 24102 & male & adult (25-35) & no statement possible & none described \\
\hline 729 & 24123 & female & adult-mature (30-45) & abscess (44) & abscess \\
\hline $840-1$ & 24162 & male & adult (20-25) & $\begin{array}{l}\text { caries on molar (38), calculus on } \\
\text { incisor (11), and canine ( } 33)\end{array}$ & remodelled periostitis \\
\hline 959 & 24267 & female & adult-mature (30-45) & $\begin{array}{l}\text { calculus on incisors }(31,32,41,42) \text {, } \\
\text { premolars }(35,44,45) \text {, and molars } \\
(37,47,48)\end{array}$ & none described \\
\hline 971 & 24280 & female & adult-mature (30-45) & $\begin{array}{l}\text { caries on premolars }(35,45) \text { and } \\
\text { molar }(37)\end{array}$ & lumbosacral transitional vertebra \\
\hline
\end{tabular}

The investigation of pathologies confirmed the findings of Wiltschke-Schrotta.

Four femora (7, 8, 840-1, and 971) exhibited an intense green discolouration and two femora showed a slight green discolouration (28 and $97^{99}$ ) (Fig. 15/a-b). The femora from

99 For an old photograph see Fig. 8. graves 7, 840-1 (Fig. 16), and 971 additionally showed brown discolouration (in individual 840-1 it was localised, in 971 the whole shaft was affected). Five femora had a brown discolouration (104, 434, 491, 662-B, and 959) (Figs. 15/c; 16), and eleven femora showed no discolouration at all $(4,37,46$, 113, 220, 230, 241, 283, 310, 347, and 729) (Table 1). No cut marks were noticed on the bones. 

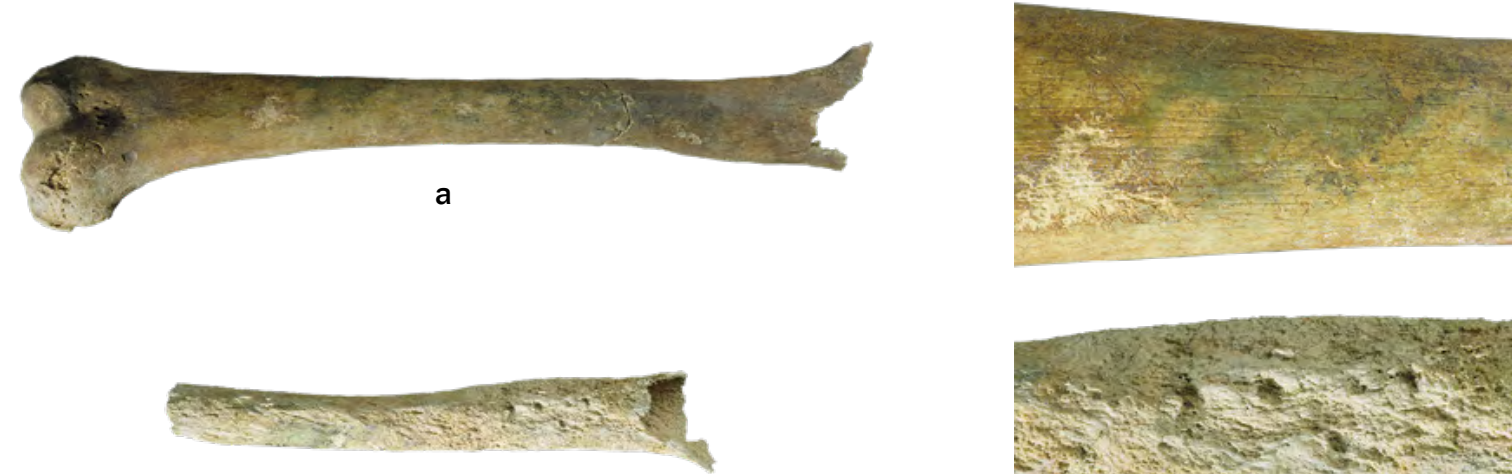

b


$20 \mathrm{~cm}$

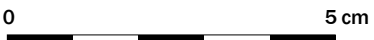

Fig. 15. External preservation and discolouration of three femora. - a. Individual 840-1 (left femur, ventral view): good external preservation, intense green and brown discolouration. - b. Individual 28 (left femur, dorsal view): bad external preservation, slight green discolouration. - c. Individual 662-B (right femur, ventral view): medium external preservation, brown discolouration (Photos: F. Novotny).

\subsection{Results of the Post-Hoc Archaeothanatological Investi- gation}

The post-hoc application of Harris and Tayles' method, ${ }^{100}$ based on the analysis of excavation records, proved to be useful in circumstances when the records were of sufficiently good quality. A challenge for the application of this technique was that many graves had already been 'plundered' during the Bronze Age. ${ }^{101}$ Within the sample of 22 graves, evidence for disturbance was present in 17 graves. Only three graves had been recorded as undisturbed (113, 230, and 347), and two as possibly undisturbed (97 and 491) (Table 1).

In terms of the original position of the corpse $\mathrm{e}^{102}$ and the presence or absence of wrapping, four skeletons $(7,28$, 104, and 729) were too severely disturbed to be included in post-hoc archaeothanatological analysis and no photos were available for graves 434 and 959. It was not possible to

100 Harris, Tayles 2012.

101 SPRENGER 1999.

102 According to Neugebauer, Neugebauer 1997, six bodies were discovered in a tightly flexed position $(97,104,241,347,491,959)$, seven showed a moderate degree of flexion $(4,8,230,310,434,840-1$, $971)$, and six had loosely flexed legs (37, 46, 113, 220, 283, 662-B). Three skeletons $(7,28$, and 729) were too disturbed to allow for reconstruction of burial positioning (see Table 1). arrive at any firm conclusions in the cases of coffin burials $220,283,310,491$, and 662-B. ${ }^{103}$

Based on the photographs, some wrapping is suggested in the cases of the lower limbs of the skeletons in coffin burials 8, 241, and 840-1 (the upper parts of the bodies were disturbed).

The photographic evidence showed two skeletons (97 and 347$)^{104}$ were very highly flexed with the legs tightly drawn up so that the femora almost touched the chest. By examining the position and rotation of bone elements, including the pelvis and patellae, and the compression of the thoracic cage, it was possible to determine that these corpses had been tightly wrapped, probably with bandages and ropes. In the Early Bronze Age at Franzhausen woven bandages would probably have been made of flax. ${ }^{105}$ The raw material for the production of ropes in Bronze Age Europe was probably tree bast, perhaps from lime trees which

103 According to Neugebauer, Neugebauer 1997, 15 bodies were buried in wooden coffins $(7,8,28,97,104,220,241,283,310,434$, $491,662-\mathrm{B}, 729,840-1$, and 959). In three cases (4, 37, and 971) coffins could not be confirmed and four bodies (46, 113, 230, and 347) were buried without coffins (see Fig. 6 and Table 1).

104 For photos of Grave 347 see Figs. 3/c and 21.

105 The remains of woven textiles made of flax were discovered in Grave 110 (Fig. 5/c): GRÖMER 2016, Fig. 199. 


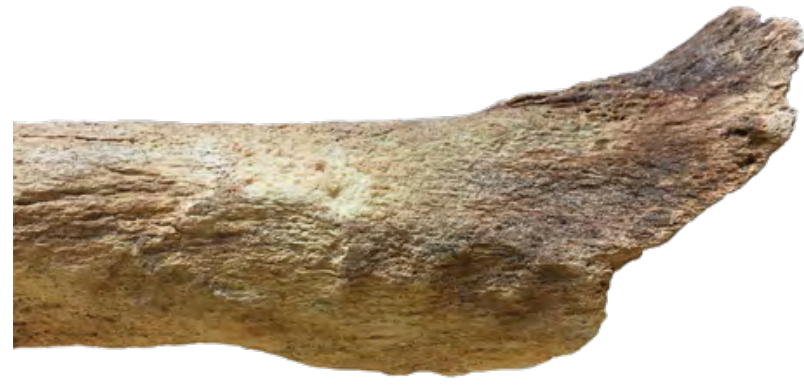

7



491

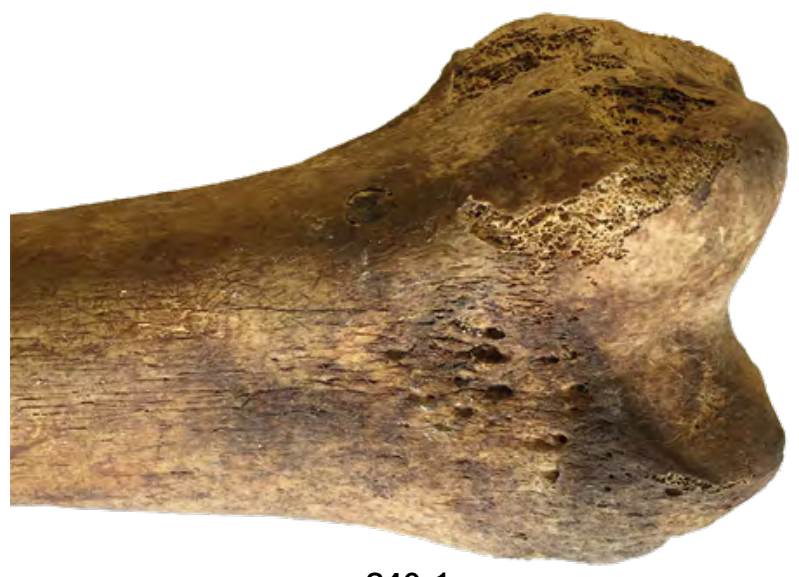

840-1

Fig. 16. Brown discolouration on femora 7, 491, and 840-1 (Photos: F. Novotny).

are particularly suitable for this purpose. ${ }^{106} \mathrm{~A}$ closer examination of the chest area of Individual 347 showed that there had been no flattening of the rib cage and no loss of volume. Since there was no coffin in this grave to protect the body, decomposition occurred within the soil rather than within the cavity formed by the coffin. Sediments ${ }^{107}$ filled the

106 Reichert 2018. - That lime trees were present in the area of Early Bronze Age Franzhausen is suggested by a piece of lime wood in Grave 241: Neugebauer, Neugebauer 1997, 195.

107 In this case humus-rich and less gravelly than the soils in coffin-less and undisturbed graves 113 and 230. thoracic void after the thoracic viscera had decomposed and prevented further movement of the ribs. ${ }^{108}$

In six other graves without coffins, compression of the thoracic cage $(4,37$, and 230) and the lower limbs (46, 113, and 971) was observed. Wrapping is a possibility but difficult to prove. In graves 113 and 230, the grave cuts (and the ceramics in Grave 230) probably prevented the displacement of the bones, in Grave 4 a stone lining may have produced a similar effect. If the soil was in contact with the corpses in graves 37,46 , and 971 it could have served as an obstacle to prevent the bones from moving. ${ }^{109}$

\subsection{Bone Microstructure}

Histological preservation across the sample was very poor and no significant differences in the preservation of the bone microstructure were found, while a loss of collagen birefringence was evident across the sample. The level of diagenesis in the bone microstructure can be described as Type III in nearly all cases with the exception of graves 37, 491, and 729 which were of Type IV and graves 7, 8, 840-1, and 971 which were of Type I. ${ }^{110}$ Within the sample of thin light sections classified as Type IV, areas of widespread crystallisation, also known as Brushite $\left(\mathrm{CaHPO}_{4} \times 2 \mathrm{H}_{2} \mathrm{O}\right)$, could be seen. ${ }^{111}$ The reason behind the state of Type IV bone preservation, irrespective of taphonomy, lies in a corrosive soil environment (acid soils, low pH-value, and high concentrations of phosphate-ions). ${ }^{112}$

The histological preservation of the 22 thin sections was defined using an OHI of 3 for best (graves 840-1 and 971) to 0 for worst histological preservation (graves 28, 37, 113, 230, and 283). The majority scored 1 (11 individuals) and four were rated as 2 (Table 1 ).

A total of 18 specimens showed evidence of microbial attack (Figs. 18-20 and Table 1). Microbial alterations caused by fungi and bacteria appeared as dark spots with blurred boundaries. In all of these cases, several types of tunnelling were observed within the thin sections. The most frequent combination (six cases) was lamellate tunnelling combined with budded tunnelling; in five cases lamellate, budded, and linear-longitudinal tunnelling occurred. In the same 18 samples enlarged osteocyte lacunae were present. Wedl-tunnelling was observed in seven samples: in one case in combination with lamellate and budded tunnelling (28), in another with budded and linear-longitudinal tunnelling (46), and in five cases associated with lamellate, budded, and

108 See Duday 2009, 52-57.

109 Duday 2009, 40.

110 SMITH et al. 2007.

111 Posner 1969. - Piepenbrink 1984, 245.

112 Nielsen-Marsh et al. 2007, 1528. 


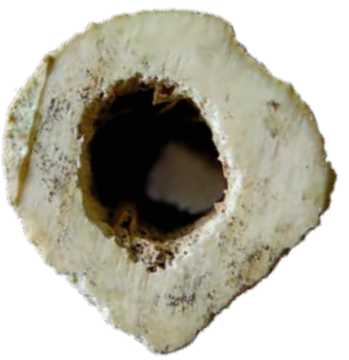

7

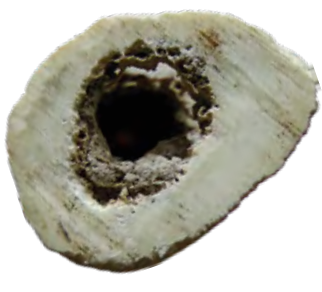

8

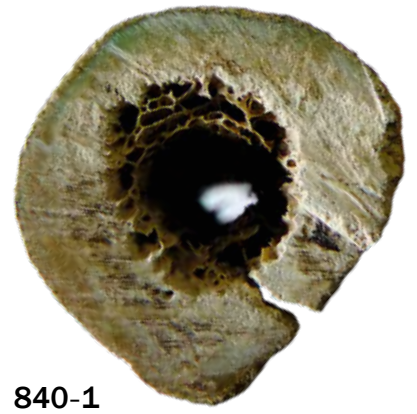

840-1

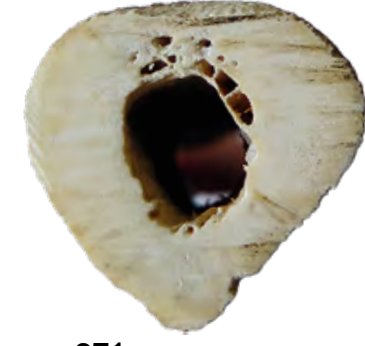

971



Fig. 17. Transverse sections of femoral diaphyses (femora 7, 8, 840-1, and 971). Note the green stain below the cortex of bone $840-1$ (Photos: E. Weiss-Krejci).

linear-longitudinal tunnelling $(4,37,104,113$, and 347). In four samples microscopic focal destruction was not visible and no enlarged lacunae were observed (graves 7, 8, 840-1, and 971) (Figs. 18-20 and Table 1). In the case of Femur 7 the good preservation of the internal bone microstructure does not correlate with the external condition of the bone (see Fig. 16).

The examination of collagen preservation using the image analysis software package KS 300 as well as the 300 -quadrant count confirmed the results outlined above. Within the FH I bone samples the quality ranged from severe destruction to excellent preservation with intact collagenous structures ( $0.25 \%$ to $6.99 \%$ ) (Table 1$)$. The best collagen preservation was observed in the four thin sections of femora 7, 8, 840-1, and 971. Individual 7 displayed 246 visible osteons in an area of c. $15 \mathrm{~mm}^{2}$ and $5.05 \%$ collagen; Individual 8 displayed 106 visible osteons and $6.99 \%$ collagen preservation; Individual 840-1, 54 visible osteons and $5.13 \%$ collagen; and Individual 971, 20 visible osteons and $5.44 \%$ collagen (Figs. 18-20 and Table 1).

\section{Discussion and Conclusions}

In order to contribute to the investigation of the emergence of elaborate forms of corpse treatment in central Europe, we launched a pilot study using material from the Early Bronze Age cemetery of Franzhausen I. We tried to answer the question of whether social distinctions and attitudes towards the dead were not only expressed through grave goods and grave construction but also through different forms of corpse preparation and treatment, such as the use of particular wrapping techniques or attempts to preserve the dead body and protect it from decay. We combined archaeological, biological (macro- and micro-morphological as well as histotaphonomic), and archaeothanatological methods.
The histotaphonomic analysis of the bone microstructure revealed a high degree of microbial tunnelling and bone alteration in 18 individuals, which we interpreted as the result of extensive post-mortem autolytic and decomposition processes. Thin sections from the three bodies that were probably disturbed while still in the process of decomposition (graves 37, 220, and 283) as well as all four undisturbed bodies (graves 113, 230, 347, and 491) showed a high level of bioerosion. They also displayed low levels of collagen preservation ranging from $0.36 \%$ to $1.44 \%$ (Table 1 ). ${ }^{113}$

A combination of Wedl and non-Wedl MFD was found in seven thin sections. This is peculiar because Wedl and non-Wedl MFD are rarely found alongside each other and are also less frequent in human than in animal bone. ${ }^{114}$ If Wedl tunnelling is associated with bone lying exposed in an open environment for some time, ${ }^{115}$ it might well explain the presence of the tunnels in individuals from disturbed graves $4,28,37,46$, and 104. However, two of the femora with Wedl tunnels came from graves that had not been disturbed before archaeological excavation (113 and 347). Currently this cannot be explained.

Bodies from graves that, judging from the drawings (Fig. 6: graves 4, 37, 347, and 729), had been dug into loamy

113 Comparative thin sections from the neighbouring Early Bronze Age cemetery of Franzhausen II (two individuals), from La Tène-period graves from Franzhausen I (five individuals), and from one femur pertaining to a medieval individual from Franzhausen revealed similar collagen content: Franzhausen II: $0.32 \%$ and $0.64 \%$; La Tène-period graves Franzhausen I: $0.11 \%, 0.67 \%, 1.12 \%$, and $3.28 \%$; medieval Franzhausen: $0.21 \%$ (a comprehensive report will be prepared by F. Novotny). This confirmed that archaeological age and the length of time a bone has been in the ground have no impact on collagen preservation. - See also Hedges, Millard, Pike 1995. 114 Jans et al. 2004, 91.

115 As suggested by Jans et al. 2004, 91. - Воотн, MaDgwick 2016, 21. 




4

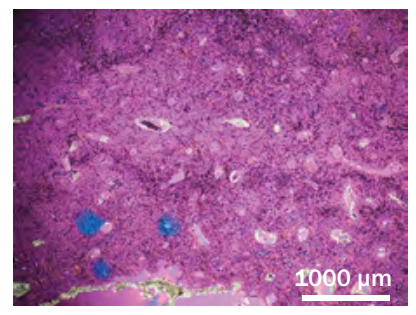

37

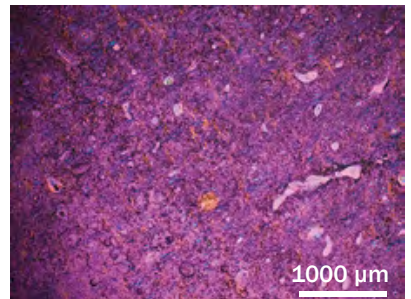

113

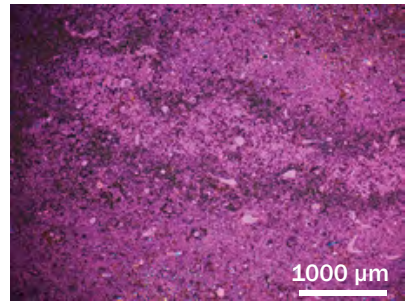

283

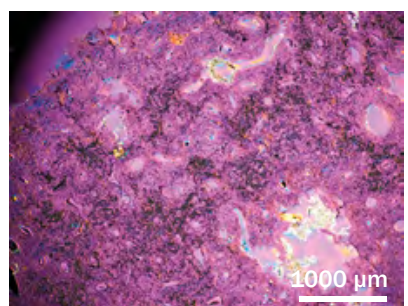

491

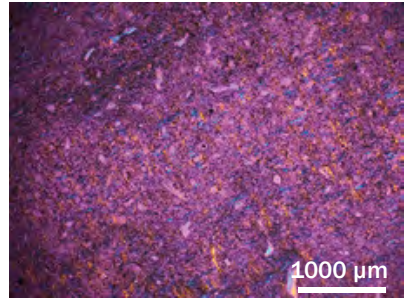

959

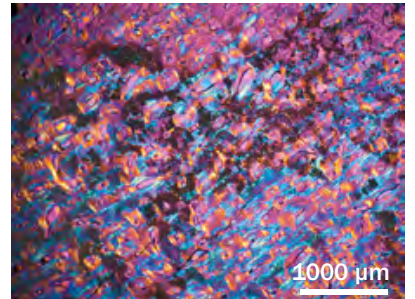

7

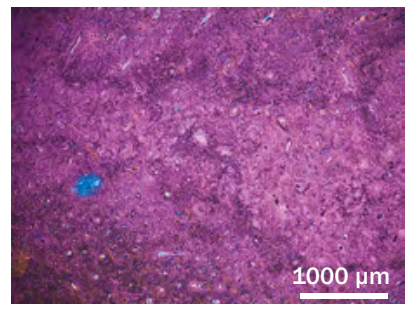

46

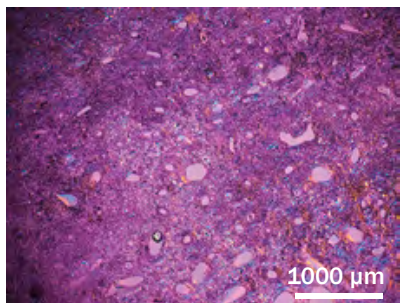

220

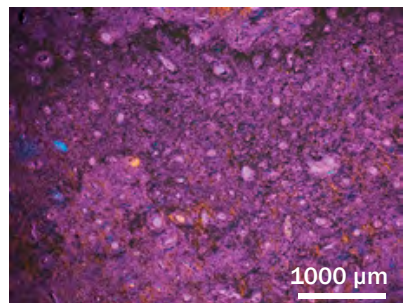

310

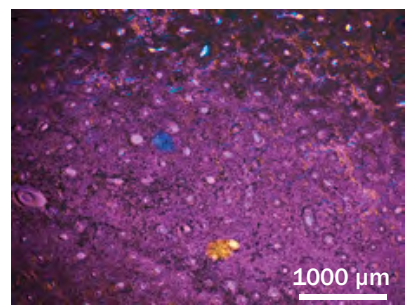

662-B

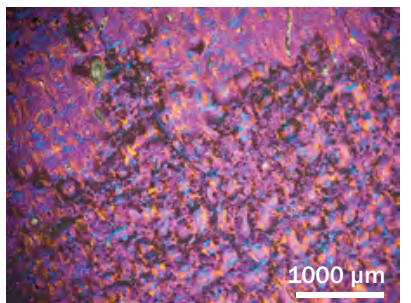

971

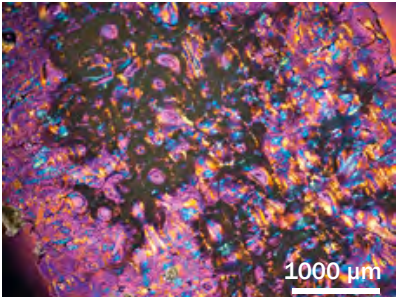

8

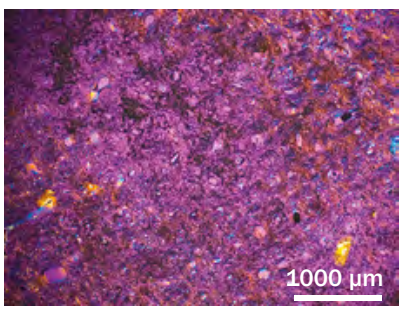

97

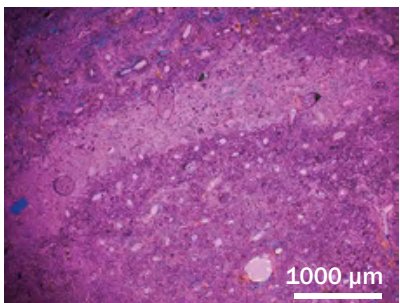

230

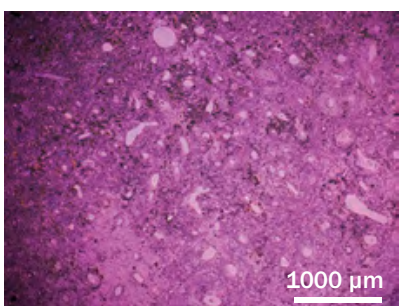

347

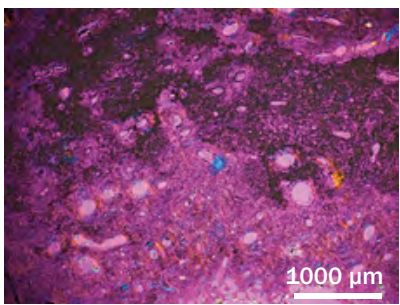

729

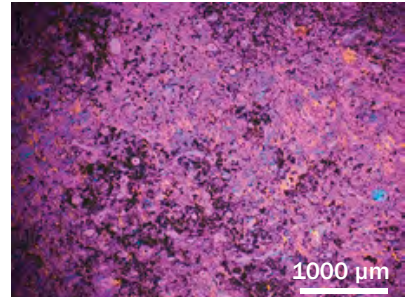

28

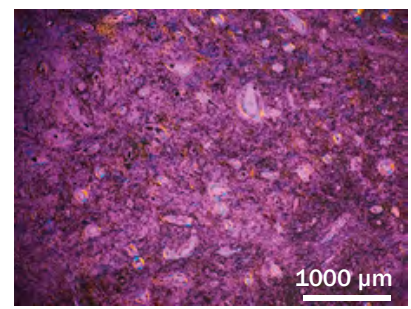

104

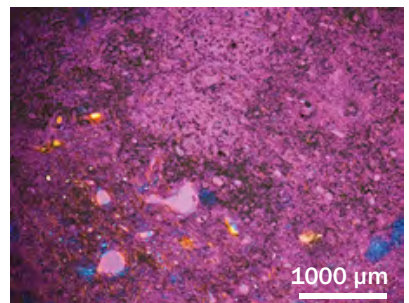

241

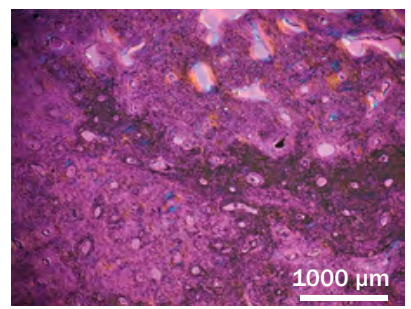

434

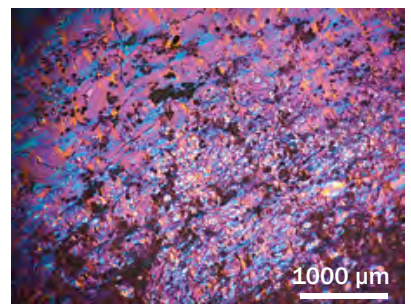

840-1

Fig. 18. Digital micrographs (20x magnification) of the 22 thin sections under polarised light using a first-order red plate (Photos: K. Mandl). 




4

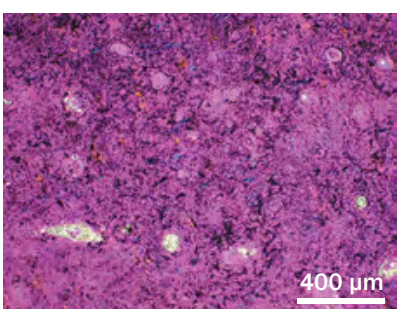

37

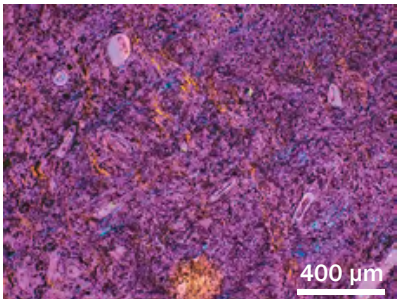

113



283

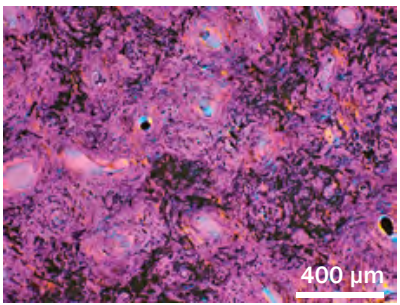

491



959

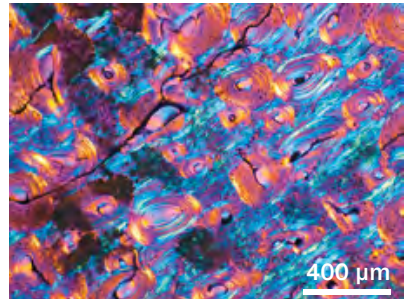

7

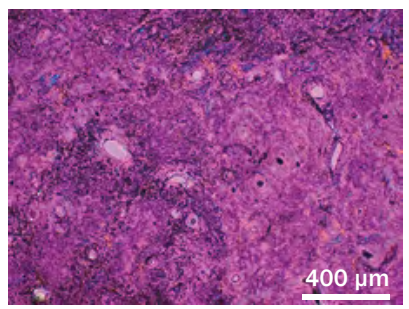

46

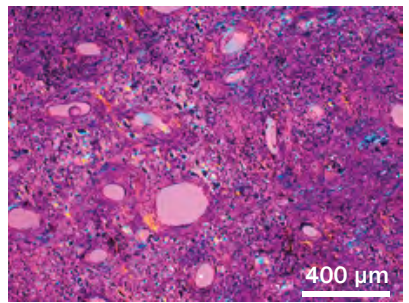

220

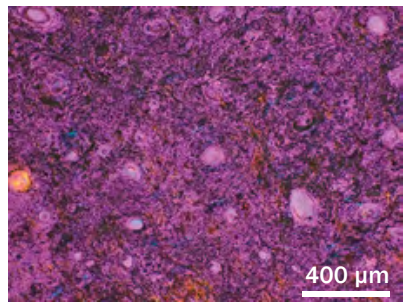

310

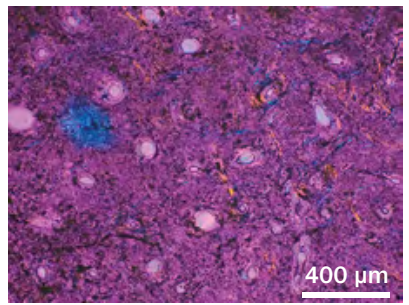

662-B

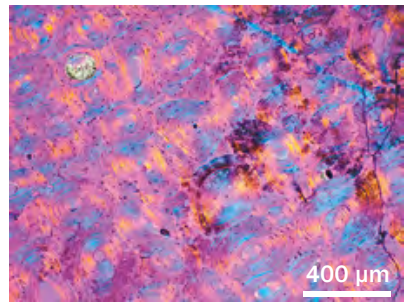

971

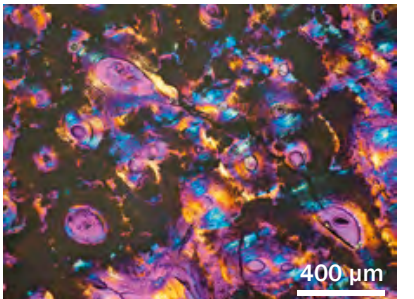

8

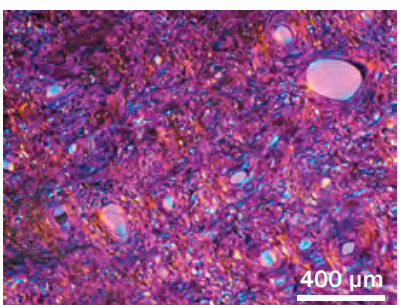

97

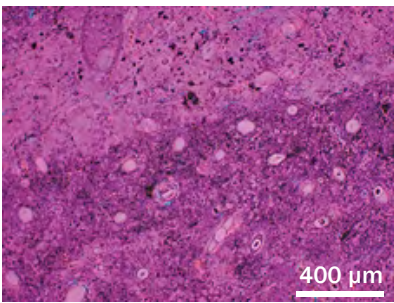

230

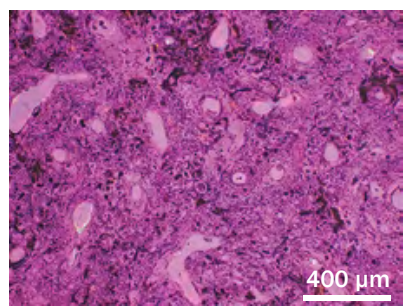

347



729



28

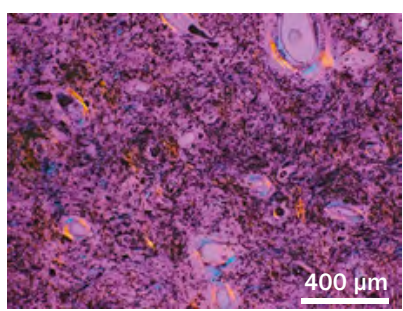

104

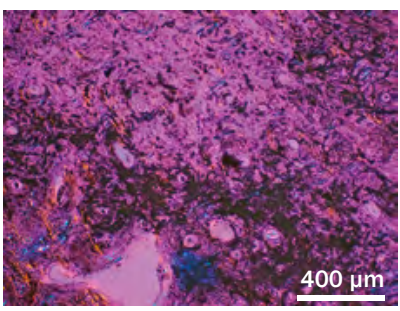

241

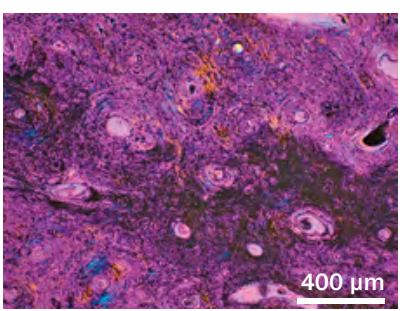

434

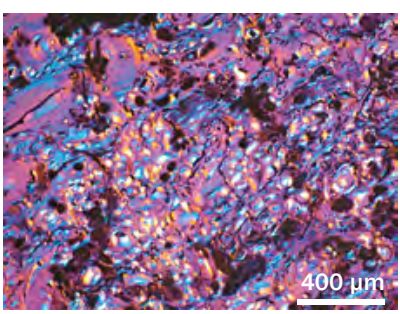

840-1

Fig. 19. Digital micrographs (50x magnification) of the 22 thin sections under polarised light using a first-order red plate

(Photos: K. Mandl). 


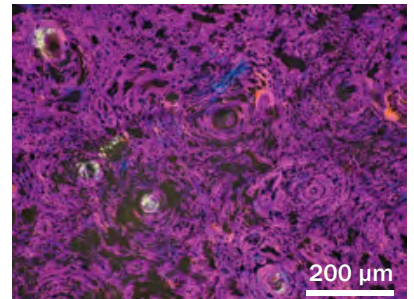

4

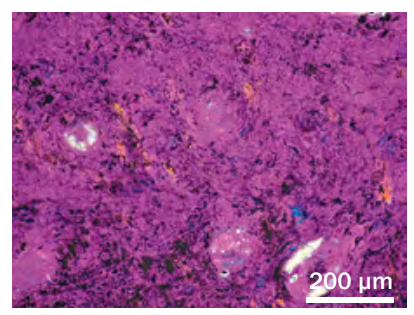

37

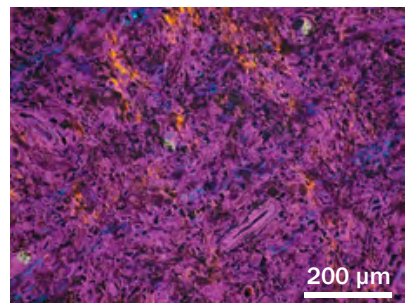

113

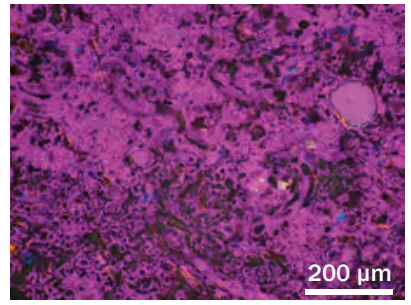

283

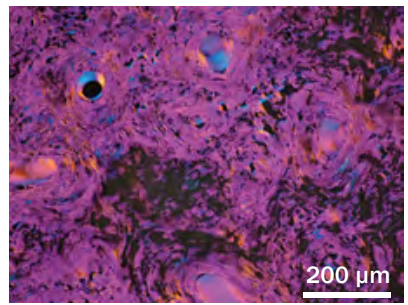

491

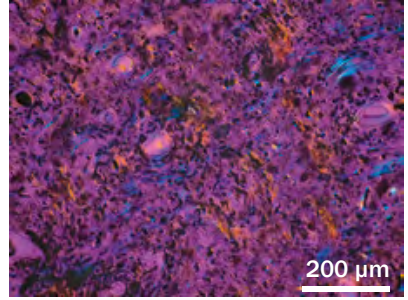

959

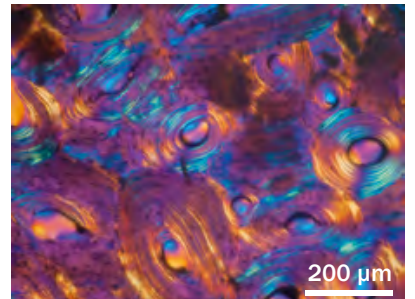

7

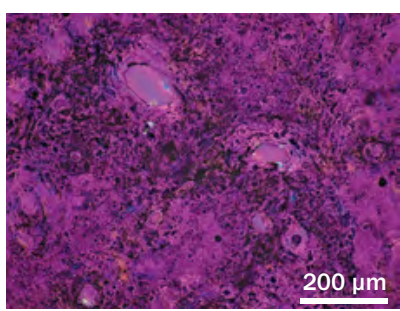

46

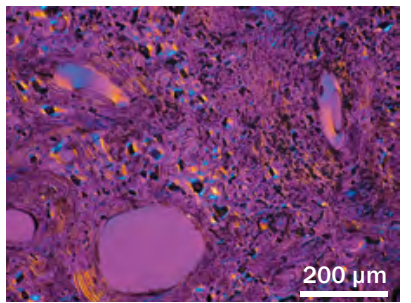

220

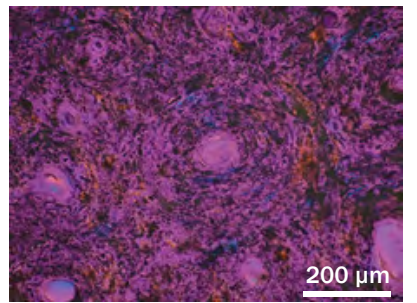

310

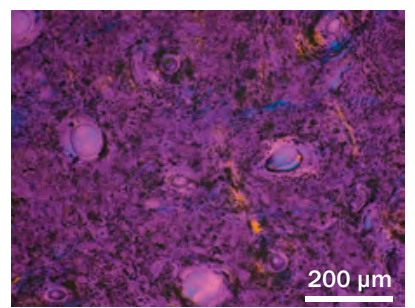

662-B

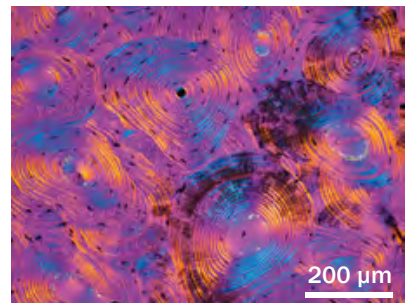

971

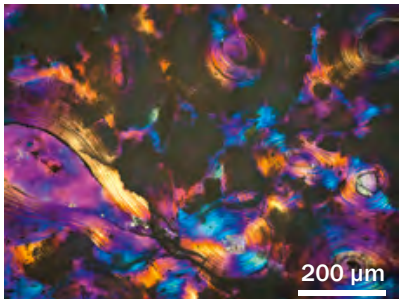

8



97

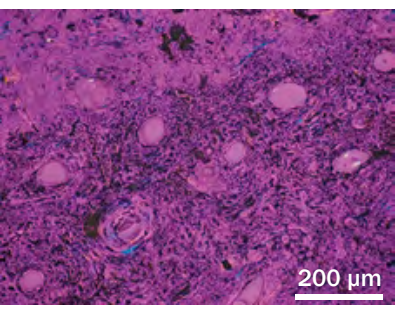

230



347

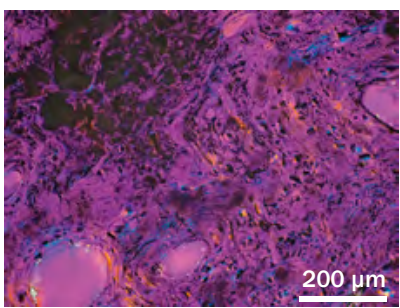

729

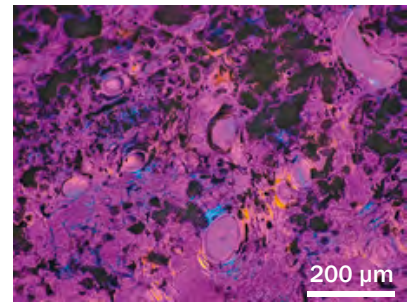

28

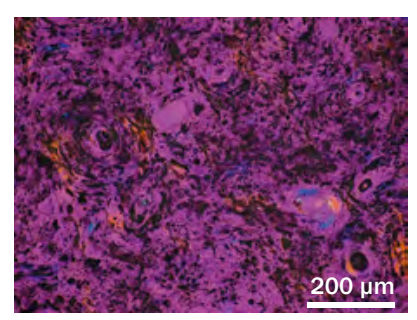

104

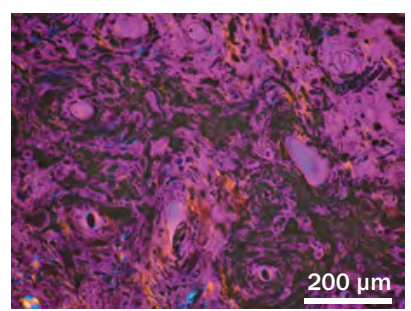

241

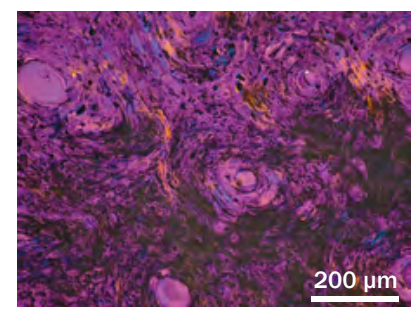

434

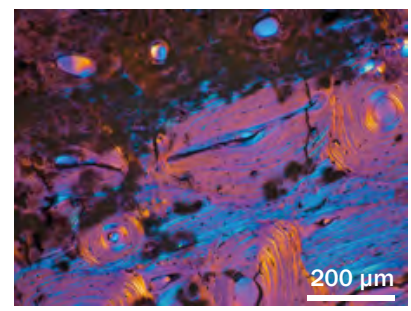

840-1

Fig. 20. Digital micrographs (100x magnification) of the 22 thin sections under polarised light using a first-order red plate (Photos: K. Mandl). 


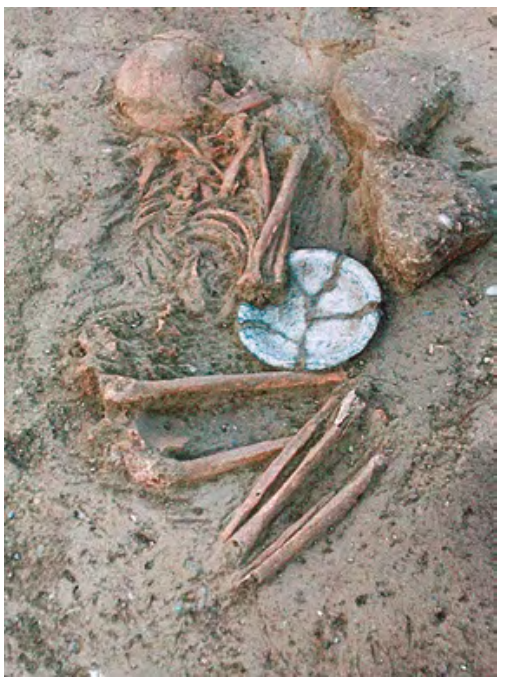

4

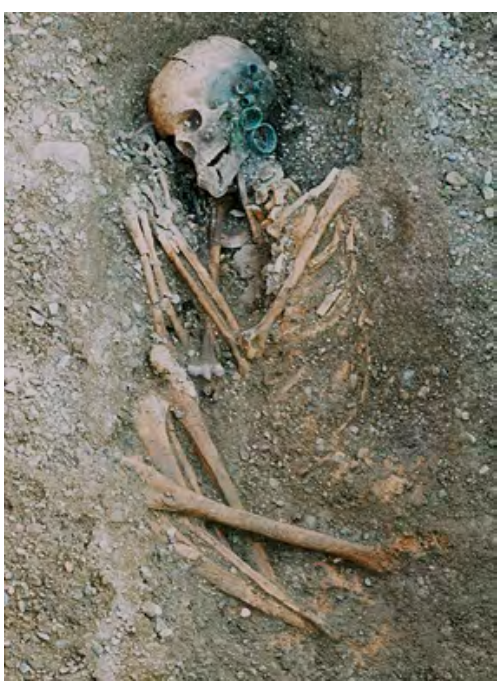

491

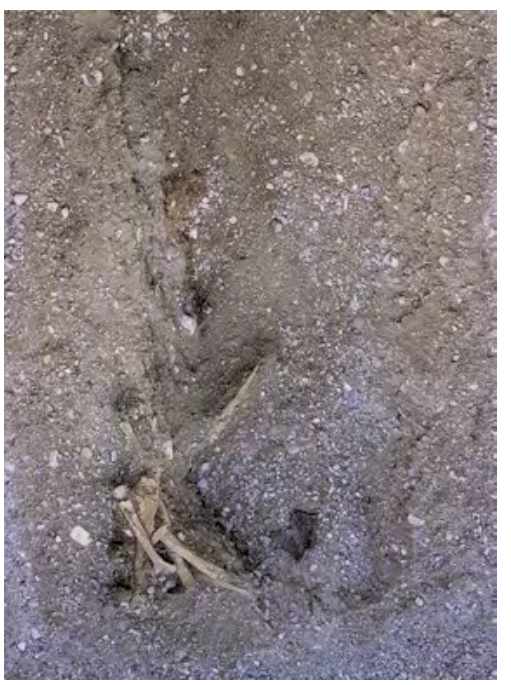

7

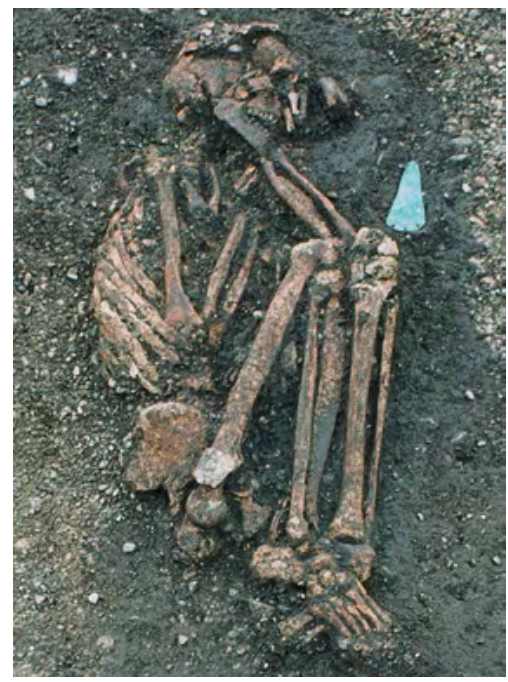

347

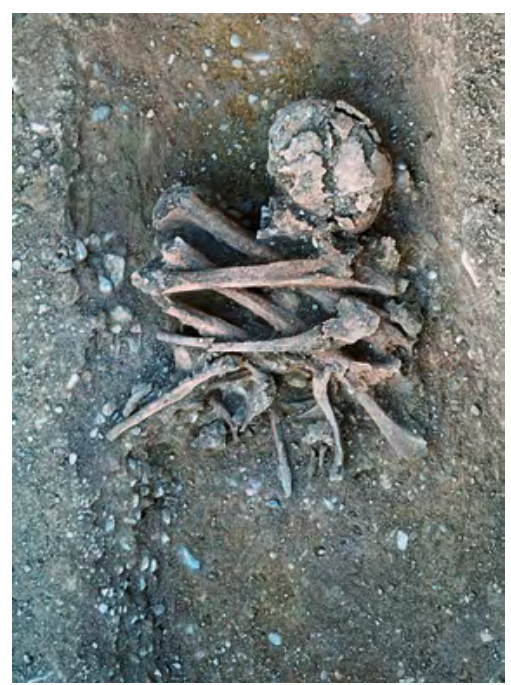

28

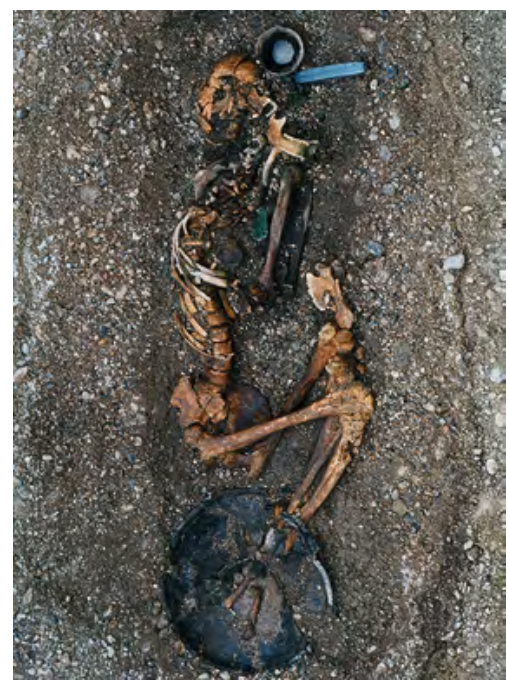

840-1

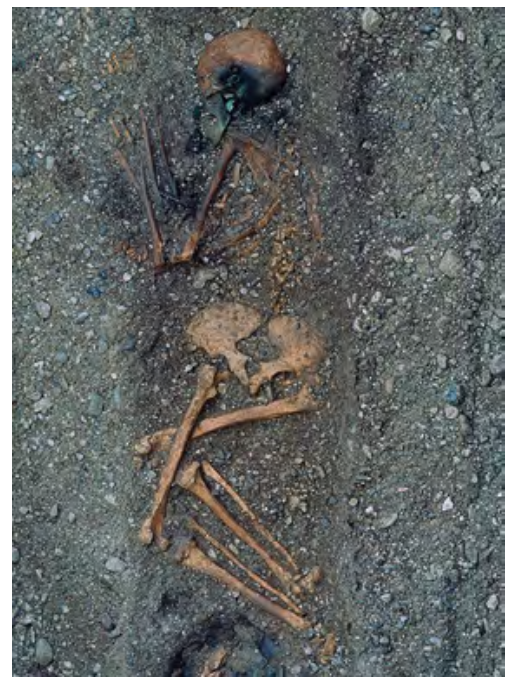

283

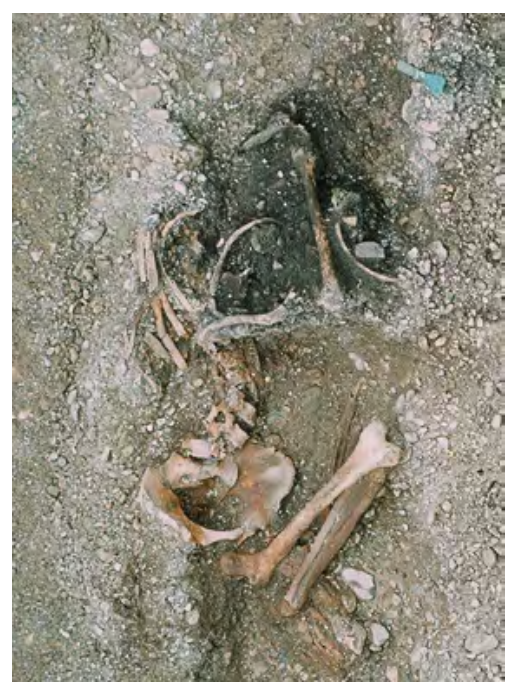

241



8

Fig. 21. Nine skeletons whose femora display variations in the preservation of the internal bone microstructure ranging from worst (upper row: graves 4, 347, 283) through intermediate (middle row: graves 491, 28, 241) to best (bottom row: graves 7, 840-1, 8) (Photos: courtesy of Federal Monuments Authority Austria, Archive Mauerbach). 
soils (see also Grave 4 in Fig. 21) and deposited with and without coffins, displayed the same high levels of bioerosion as bones deposited with or without coffins in sandy or gravelly soil (e.g. 46, 113, 230, and 662-B).

The femora of four Early Bronze Age individuals (7, 8, 804-1, and 971) displayed a partially intact microstructure with minor areas of bone destruction. These four individuals (two adult mature females, one mature senile female, and one adult male) also showed the highest amount of collagenous remnants in any of the individuals analysed (Table 1). This suggests that the microbial invasion accompanying putrefaction was stopped. If this were so, what factors might have been responsible?

Grave depth, the presence of coffins, sex, age, body position, and the presence of bronze objects do not explain the variations in the state of preservation (Fig. 21). The depth of the four graves ranged from 140 to $242 \mathrm{~cm}$, three graves $(7$, 8 , and 840-1) contained coffins, but the presence of a coffin could not be firmly established in the case of Grave 971. Since the soils of graves 7, 8, 840-1, and 971 were mainly composed of well-drained gravel (Figs. 6; 21), an anoxic or waterlogged environment ${ }^{116} \mathrm{can}$ be ruled out as the cause of decelerated decomposition and bioerosion.

It looks as if bodies 8 and $840-1$ were wrapped. However, at FH I there is no direct connection between wrapping and a good preservation of the microstructure since the wrapped bodies from graves 97 and 347 (Figs. 3/c; 21) were in very poor condition: in Individual 347 non-Wedl MFD were present, no osteons were visible and collagen preservation was as low as $0.47 \%$. Some bones showed periosteal erosion, but no evidence for excarnation or evisceration could be detected. The vertebrae of neck and chest, ribs, the inner surface of the pelvis (Os sacrum and coxae), and the joints of the long bones did not reveal any ancient cut marks. Hence, the pre-depositional active excarnation of disarticulated individuals seems unlikely. ${ }^{117}$

When analysed macroscopically, the four femora of the individuals from graves 7, 8, 840-1, and 971 exhibited intense green discolouration (Figs. 15/a; 17). The femora from 7, 840-1 (Fig. 16), and 971 also showed brown discolouration. While Femora 8, 840-1, and 971 displayed a good state of surface preservation, Femur 7's surface (Fig. 16) was rather more eroded.

The brown discolouration - also visible on femora 104, 434, 491 (Fig. 16), 662-B (Fig. 15/c), and 959 - might derive from the decomposition of organic matter such as a coffin.

116 Turner-Walker 2008, 20-22. - Booth 2016.

117 The bone surface of Individual 7 was eroded. Had there once been cut marks they would not be visible any longer.
Similar dark brown staining was observed in the thin sections of a coffin burial from Canada Farm, which showed excellent preservation. ${ }^{118}$ To our knowledge, there exists no empirical evidence to show that either groundwater or the liquids resulting from decomposition seeping through oak coffins can absorb enough tannin to exert a tanning effect on fresh corpses. ${ }^{119}$ Femora that were only stained brown but not green (104, 434, 491, 662-B, and 959) all displayed microbial tunnelling. ${ }^{120}$

While the above mentioned study by Müller and colleagues on animal bones from Paris proved a connection between green staining on bones and heavy metal uptake, the results were less conclusive when considering the inhibitor effect of heavy metals on microbial activities and diagenetic changes. Although samples not enriched in metals displayed extensive alterations caused by micro-organisms and two-thirds of the bones containing high amounts of heavy metals showed no alterations linked to bacteria, Müller and colleagues observed microbial attack in a couple of bones containing high amounts of copper, zinc, and lead. ${ }^{121}$ It seems that there are potential complexities that cannot be explained at present.

We suggest that post-depositional diffusion of heavy metals eroding from copper and bronze grave goods, mediated by tissue liquefaction and moisture building in coffins, were the prime cause of the preservation of the internal bone microstructure. In our sample, the effect of bronze artefacts on early taphonomic processes is clearly shown in the thin sections (e.g. Femur 971 in Fig. 9). These expose central endogenous bioerosion and decelerated degradation with well-preserved microstructure near the bone cortex.

In summary, at the present we cannot prove that dead bodies underwent deliberate mummification treatment at FH I, nor disprove it; especially considering our relatively small sample size in relation to the large number of excavated graves. However, given our results, we currently lean towards the assumption that even the four well-preserved individuals in graves 7, 8, 804-1, and 971 had originally been buried in the flesh. In order to clarify whether corpses had decomposed in the grave, further investigation is required. In the future, phosphate analysis should also be extensively applied during the excavation of cemeteries. ${ }^{122}$ This will assist our understanding of how corpses were treated in Bronze Age central Europe.

118 Sмiтh et al. 2016, Fig. 2/b.

119 As suggested by Aufderheide 2003, 59.

120 The remains of oak wood were found in graves 97 and 283 (the investigated femora are not stained brown).

121 Müller et al. 2011, 48-50.

122 ERNÉE 2013, 229. 


\section{Acknowledgements}

The article forms part of the project Deploying the Dead: Artefacts and Human Bodies in Socio-Cultural Transformations (DEEPDEAD), which has received funding from the HERA Joint Research Programme 'Uses of the Past' (UP) [Collaborative Research Project (CRP) no. 15.055] and the European Union's Horizon 2020 research and innovation programme under grant agreement No 649307. We would like to thank Christoph Blesl and Stephan Kraus for access to the archaeological photo archives in Mauerbach and Katharina Rebay-Salisbury, Christine Neugebauer-Maresch, and Peter Stadler for providing additional materials. We also benefited from the expertise of Marianne Kohler-Schneider and thank her for her valuable suggestions on plants used for making string, cord, and rope in prehistoric Europe. Thanks are extended to Wolfgang Reichmann from the Natural History Museum in Vienna for photographing thin sections and photo slides, and Karin Wiltschke-Schrotta and colleagues of the Department of Anthropology at the Natural History Museum in Vienna for general assistance. We are very grateful for suggestions and comments concerning microbiological analysis made by David Brönnimann and Cordula Portmann from the Institute for Integrative Prehistory and Archaeological Science, University of Basel. Finally, yet importantly, we thank the two anonymous reviewers for their valuable input and useful remarks.

\section{Author Contributions}

Kirsten Mandl: concept, methodology, macroscopic skeletal analysis, post-hoc archaeothanatology, microphotography, histotaphonomy (determination of diagenesis, OHI, MFD, image analysis), writing

Friederike Novotny: methodology, thin sections, macroscopic skeletal analysis, microphotography, histology (computerised digital image analysis), writing

Maria Teschler-Nicola: methodology, macroscopic skeletal analysis, writing

Estella Weiss-Krejci: concept, funding acquisition, archaeological analysis, writing

\section{References}

ACSÁdi, NeMESKÉRI 1970

G. AcsÁdi, J. Nemeskéri, History of Human Life Span and Mortality. Budapest 1970.

Assis et al. 2015

S. Assis, A. Keenleyside, A. L. Santos, F. Alves Cardoso, Bone diagenesis and its implication for disease diagnosis: the relevance of bone microstructure analysis for the study of past human remains, Microscopy and Microanalysis 21/4, 2015, 805-825.

Aspöck, BANERJEA 2016

E. Aspöck, R. Y. BAnerJeA, Formation processes of a reopened early Bronze Age inhumation grave in Austria: the soil thin section analyses, Journal of Archaeological Science: Reports 10, 2016, 791-809.

Aufderheide 2003

A. C. Aufderheide, The Scientific Study of Mummies. Cambridge 2003.

BARBER 1987

P. BARBER, Forensic pathology and the European vampire, Journal of Folklore Research 24/1, 1987, 1-32.
BeCKetT et al. 2017

R. G. Beckett, G. J. Conlogue, O. V. Abinion, A. SalvaDoR-Amores, D. Piombino-Mascali, Human mummification practices among the Ibaloy of Kabayan, North Luzon, The Philippines, Papers on Anthropology 26/2, 2017, 24-37.

BeLl, Skinner, Jones 1996

L. S. Bell, M. F. Skinner, S. J. Jones, The speed of post mortem changes to the human skeleton and its taphonomic significance, Forensic Sciences International 82/2, 1996, 129-140.

BERNER 1988

M. BERNER, Das frühbronzezeitliche Gräberfeld von Franzhausen I: Demografische und metrische Analyse. Unpublished PhD Dissertation, University of Vienna 1988.

BERNER 1992

M. BERNER, Das frühbronzezeitliche Gräberfeld von Franzhausen I, Niederösterreich 2: Demografische Analyse, Anthropologischer Anzeiger 50/1-2, 1992, 13-26.

BERNER, WILTSCHKE-SCHROTTA 1992

M. Berner, K. Wiltschke-Schrotta, Das frühbronzezeitliche Gräberfeld von Franzhausen I, Niederösterreich 1: Allgemeine Übersicht, Anthropologischer Anzeiger 50/1-2, 1992, 1-12.

BINFORD 1971

L. BINFORD, Mortuary practices: their study and their potential. In: J. A. Brown (Ed.), Approaches to the Social Dimensions of Mortuary Practices. Society of American Archaeology Memoirs 25, Washington D.C. 1971, 6-29.

Воотн 2016

T. J. Воотн, An investigation into the relationship between funerary treatment and bacterial bioerosion in European archaeological human bone, Archaeometry 58/3, 2016, 484-499.

Воотн 2017

T. Воотн, The rot sets in: low-powered microscopic investigation of taphonomic changes to bone microstructure and its application to funerary contexts. In: D. ERrickson, T. ThOMpson (Eds.), Human Remains: Another Dimension. The Application of Imaging to the Study of Human Remains. London 2017, 7-28.

Booth, Chamberlain, Parker Pearson 2015

T. J. Booth, A.T. Chamberlain, M. Parker Pearson, Mummification in Bronze Age Britain, Antiquity 89/347, 2015, 1155-1173.

Booth, Madgwick 2016

T. J. Воотн, R. MADGwick, New evidence for diverse secondary burial practices in Iron Age Britain: a histological case study, Journal of Archaeological Science 67, 2016, 14-24.

Bosch 2008

T. L. Bosch, Archäologische Untersuchungen zur Frage von Sozialstrukturen in der Ostgruppe des Glockenbecherphänomens anhand des Fundgutes. PhD Dissertation, University of Regensburg 2008, http://urn:nbn:de:bvb:355-opus-12922 (last accessed 22.4.2018).

BosKey 2013

A. L. Boskey, Bone composition: relationship to bone fragility, and antiosteoporotic drug effects, BoneKEy Reports 2/447, 2013. doi: 10.1038/bonekey.2013.181

Boulestin, Duday 2006

B. Boulestin, H. DudAY, Ethnology and archaeology of death: from the illusion of references to the use of a terminology, Archaeologia Polona, 44, 2006, 149-169. 
BREUNING-MadSEN et al. 2003

H. Breuning-Madsen, M. K. Holst, M. Rasmussen, B. Elberling, Preservation within log coffins before and after barrow construction, Journal of Archaeological Science 30/3, 2003, 343-350.

Brönnimann, Portmann, Pichler 2017

D. Brönnimann, C. Portmann, S. Pichler, Dust 'n' bones - combining anthropology and geoarchaeology as a promising tool for bone taphonomy. Paper held at the $23^{\text {rd }}$ Annual Meeting of the European Association of Archaeologists, 30 $0^{\text {th }}$ August $-3^{\text {rd }}$ September, 2017, Maastricht.

BRUNDAGE 1963

B. C. BRundage, Empire of the Inca. Norman 1963.

CARr 1995

C. CARr, Mortuary practices: their social, philosophical-religious, circumstantial and physical determinants, Journal of Archaeological Method and Theory 2/2, 1995, 105-200.

CHILd 1995

A. M. Child, Towards an understanding of the microbial decomposition of archaeological bone in the burial environment, Journal of Archaeological Science 22/2, 1995, 165-174.

Deviese et al. 2010

T. Deviese, M. P. Colombini, M. Regert, B. H. Stuart, J. P. GuerBOIs, TG-MS analysis of archaeological bone from burials of the late Roman period, Journal of Thermal Analysis and Calorimetry 99/3, 2010, 811-813.

DUDAY 2009

H. Duday, The Archaeology of the Dead: Lectures in Archaeothanatology. Oxford 2009.

ERNÈE 2013

M. ERNÈE, Uniformität oder Kreativität im Totenbrauchtum? Zum Bestattungsritus der Aunjetitzer Kultur aus Sicht der Phosphatanalyse. In: Müller-ScheEssel, N. (Ed.), ,Irreguläre‘ Bestattungen in der Urgeschichte: Norm, Ritual, Strafe ...? Akten der Internationalen Tagung in Frankfurt am Main, 3.-5. Februar 2012. Kolloquien zur Vor- und Frühgeschichte 19, Bonn 2013, 227-238.

Ferembach, Schwidetzky, Stloukal 1979

D. Ferembach, I. Schwidetzky, M. Stloukal, Empfehlungen für die Alters- und Geschlechtsdiagnose am Skelett, Homo 30, 1979, $1-32$.

FERNÁNDEZ-JaLVo et al. 2002

Y. Fernández-Jalvo, B. Sánchez-Chillón, P. Andrews, S. Fernández-López, L. Alcalá Martínez, Morphological taphonomic transformations of fossil bones in continental environments, and repercussions on their chemical composition, Archaeometry 44/3, 2002, 353-361.

FERnÁNDEZ-Jalvo et al. 2010

Y. Fernández-Jalvo, P. Andrews, D. Pesquero, C. Smith, D. Marín-Monfort, B. Sánchez, E.-M. Geigl, A. Alonso, Early bone diagenesis in temperate environments. Part I: surface features and histology, Palaeogeography, Palaeoclimatology, $\mathrm{Pa}$ laeoecology 288, 2010, 62-81.

Fourie 1928

L. Fourie, The Bushmen of South West Africa. In: C. H. L. Hahn, L. Fourie, H. Vedder, The Native Tribes of South West Africa. Cape Town 1928, 79-105.

GARLAND 1987

A. N. GARLAND, A histological study of archaeological bone decomposition. In: A. Boddington, A. N. Garland, R. C. Janaway
(Eds.), Death, Decay and Reconstruction: Approaches to Archaeology and Forensic Science. Manchester 1987, 109-126.

Gordon, BuIKSTRA 1981

C. C. Gordon, J. E. Buikstra, Soil pH, bone preservation, and sampling bias at mortuary sites, American Antiquity 46/3, 1981, 566-571.

GRÖMER 2016

K. Grömer, The Art of Prehistoric Textile Making. Vienna 2016.

Grupe, Harbeck, McGlynn 2015

G. Grupe, M. Harbeck, G. C. McGlynn, Prähistorische Anthropologie. Berlin - Heidelberg 2015.

НACKETT 1981

C. J. Hacketт, Microscopical focal destruction (tunnels) in excavated human bones, Medicine, Science and Law 21/4, 1981, 243-265.

Hanna et al. 2012

J. Hanna, A. S. Bouwman, K. A. Brown, M. Parker Pearson, T. A. Brown, Ancient DNA typing shows that a Bronze Age mummy is a composite of different skeletons, Journal of Archaeological Science 39/8, 2012, 2774-2779.

HARRIS, TAYles 2012

N. J. HARRIS, N. TAYLES, Burial containers - a hidden aspect of mortuary practices: archaeothanatology at Ban Non Wat, Thailand, Journal of Anthropological Archaeology 31/2, 2012, 227-239.

Hedges, Millard 1995

R. E. M. Hedges, A. R. Millard, Bones and groundwater: towards the modelling of diagenetic processes, Journal of Archaeological Science 22/2, 1995, 155-164.

Hedges, Millard, Pike 1995

R. E. M. Hedges, A. R. Millard, A. W. G. Pike, Measurements and relationships of diagenetic alteration of bone from three archaeological sites, Journal of Archaeological Science 22/2, 1995, 201-209.

Hochmeister, Grassberger, STIMPfl 2007

M. Hochmeister, M. Grassberger, T. Stimpfl, Forensische Medizin für Studium und Praxis. Vienna 2007.

Hollund et al. 2012

H. I. Hollund, M. M. E. Jans, M. J. Collins, H. Kars, I. Joosten, S. M. KARs, What happened here? Bone histology as a tool in decoding the postmortem histories of archaeological bone from Castricum, The Netherland, International Journal of Osteoarchaeology 22/5, 2012, 537-548.

Holst, Breuning-Madsen, Rasmussen 2001

M. K. Holst, H. Breuning-Madsen, M. Rasmussen, The South Scandinavian barrows with well-preserved oak-log coffins, Antiquity $75 / 287,2001,126-136$.

ISERSON 1994

K. V. Iserson, Death to Dust: What Happens to Dead Bodies. Tucson 1994.

JACKES et al. 2001

M. Jackes, R. Sherburne, D. Lubell, C. Barker, M. Wayman, Destruction of microstructure in archaeological bone: a case study from Portugal, International Journal of Osteoarchaeology 11/6, 2001, 415-432.

JANAWAY 1987

R. C. JANAWAY, The preservation of organic materials in association with metal artefacts deposited in inhumation graves. In: A. BoDDington, A. N. Garland, R. C. Janaway (Eds.), Death, Decay and Reconstruction: Approaches to Archaeology and Forensic Science. Manchester 1987, 127-148. 


\section{JANAWAY 1996}

R. C. JANAWAY, The decay of human remains and their associated materials. In: J. Hunter, C. Roberts, A. Martin (Eds.), Studies in Crime: An Introduction to Forensic Archaeology. London 1996, $58-85$.

Jans et al. 2004

M. M. E. Jans, C. M. Nielsen-Marsh, C. I. Smith, M. J. Collins, H. KARs, Characterisation of microbial attack on archaeological bone, Journal of Archaeological Science 31/1, 2004, 87-95.

Keller, Teschler-Nicola 2013

C. Keller, M. Teschler-Nicola, Frakturen als Indikatoren für Gewalt und Grabstörungen - Möglichkeiten und Grenzen, Mitteilungen der Anthropologischen Gesellschaft in Wien 143, 2013, $113-130$.

KERLEY 1965

E. R. Kerley, The microscopic determination of age in human bone, American Journal of Physical Anthropology 23, 1965/2, 146-164.

KeRLey, Ubelaker 1978

E. R. Kerley, D. H. Ubelaker, Revisions in the microscopic method of estimation age at death in human cortical bone, American Journal of Physical Anthropology 49/4, 1978, 545-546.

KNIPPER et al. 2017

C. Knipper, A. Mittnik, K. Massy, C. Kociumaka, I. Kucukkalipci, M. Maus, F. Wittenborn, S. E. Metz, A. Staskiewicz, J. Krause, P. W. Stockhammer, Female exogamy and gene pool diversification at the transition from the Final Neolithic to the Early Bronze Age in central Europe, PNAS 114/38, 2017, 10083-10088.

KNÜSEL 2014

C.J. KNÜsEL, Crouching in fear: terms of engagement for funerary remains, Journal of Social Archaeology 14/1, 2014, 26-58.

KREUTZ 2014

D. KREUTZ, Elemental and isotopic analysis by (multiple collector) - inductively coupled plasma mass spectrometry in human teeth from the Early Bronze Age excavation site Franzhausen I (Lower Austria) for the investigation of population dynamics and dietary patterns. Unpublished thesis, University of Vienna 2014.

LOBISSER, KERN 2017

W. F. A. Lobisser, D. Kern, Lanze, Pfriem und Muschelschmuck: Experimentelle Nachbauten von Objekten aus tierischen Rohstoffen nach Originalen aus endneolithischen Gräbern des Unteren Traisentals, Archaeologia Austriaca 101, 2017, 45-71.

MAAT et.al. 2006

G. J. R. MaAt, A. Maes, M. J. Aarents, N. J. D. Nagelkerke, Histological age prediction from the femur in a contemporary Dutch sample: the decrease of nonremodeled bone in the anterior cortex, Journal of Forensic Science 51/2, 2006, 230-237.

Mant 1987

A. K. Mant, Knowledge from post-War exhumations. In: A. BodDington, A. N. Garland, R. C. Janaway (Eds.), Death, Decay and Reconstruction: Approaches to Archaeology and Forensic Science. Manchester 1987, 65-80.

Marchiafava, Bonucci, Ascenzi, 1974

V. Marchiafava, E. Bonucci, A. Ascenzi, Fungal osteoclasia: a model of dead bone resorption, Calcified Tissue Research 14/1, 1974, 195-210.

McEwan 2006

G. McEwan, The Incas: New Perspectives. New York 2006.
MiLes 1963

A. E. W. Miles, The dentition in the assessment of individual age in skeletal material. In: D. R. BRoTHWELl (Ed.), Dental Anthropology. Symposia of the Society for the Study of Human Biology 5 , 1963, 191-209.

MüLLER et al. 2011

K. Müller, C. Chadefaux, N. Thomas, I. Reiche, Microbial attack of archaeological bones versus high concentrations of heavy metals in the burial environment: a case study of animal bones from a mediaeval copper workshop in Paris, Palaeogeography, Palaeoclimatology, Palaeoecology 310, 2011, 39-51.

Neugebauer 1987

J.-W. Neugebauer, Die Bronzezeit im Osten Österreichs. Forschungsberichte zur Ur- und Frühgeschichte 13, St. Pölten - Vienna 1987.

Neugebauer 1991

J.-W. Neugebauer, Die Nekropole F von Gemeinlebarn, Niederösterreich: Untersuchungen zu den Bestattungssitten und zum Grabraub in der ausgehenden Frühbronzezeit in Niederösterreich südlich der Donau zwischen Enns und Wienerwald. Römisch-Germanische Forschungen 49, Mainz 1991.

Neugebauer, Neugebauer 1997

C. Neugebauer, J.-W. Neugebauer, Franzhausen: Das frühbronzezeitliche Gräberfeld I. Fundberichte aus Österreich, Materialhefte A5/1-2, Horn 1997.

Neugebauer, Neugebauer-Maresch 1988

J.-W. Neugebauer, C. Neugebauer-Maresch, Das frühbronzezeitliche Hockergräberfeld Franzhausen I in urgeschichtlicher Sicht. In: Mensch und Kultur der Bronzezeit. Katalog der Sonderausstellung des Museums für Urgeschichte in Asparn/Zaya 1988, Katalog des Landesmuseums N.F., Vienna 1988, 16-36.

Neugebauer-Maresch 2016

C. Neugebauer-Maresch, Medizinische Versorgung für alle? Gedanken zu einigen Individualbefunden aus dem frühbronzezeitlichen Gräberfeld Franzhausen I. In: M. Bartelheim, B. Horejs, R. Krauss (Eds.), Von Baden bis Troia: Ressourcennutzung, Metallurgie und Wissenstransfer. Oriental and European Archaeology 3, Rahden/Westf. 2016, 235-249.

Nielsen-Marsh et al. 2007

C. M. Nielsen-Marsh, C. Smith, M. M. E. Jans, M. J. Collins, Bone diagenesis in European Holocene II: taphonomic and environmental consideration, Journal of Archaeological Science 34/9, 2007, 1523-1531.

NiLsson STUTZ 2006

L. NiLsson STUTZ, Unwrapping the dead: searching for evidence of wrappings in the mortuary practices at Zvejnieki. In: L. LARssON, I. ZAGORSKA (Eds.), Back to the Origin: New Research in the Mesolithic-Neolithic Zvejnieki Cemetery and Environment, Northern Latvia. Stockholm 2006, 217-233.

NiLsSON STUTZ 2008

L. NILSSON STUTZ, More than metaphor: approaching the human cadaver in archaeology. In: F. FAHLANder, T. OestigaArd (Eds.), The Materiality of Death. Oxford 2008, 19-28.

Novotny et al. 2003

F. Novotny, M. Teschler-Nicola, T. Prohaska, C. Latkoczy, G. STINGEDER, Diagenetic alterations in archaeological human skeletal remains via light microscopy and their implications, American Journal of Physical Anthropology Suppl. 36, 2003, 159. 
ÖSTERREICHISCHE DigitALE BODENKARTE

eBOD, http://gis.lebensministerium.at/eBOD/frames/index. php?\&146=true\&gui_id=eBOD (last accessed 17.6.2017).

OtTONi et al. 2009

C. Ottoni, H. E. Koon, M. J. Collins, K. E. Penkman, O. Rickards, O. E. CRAIG, Preservation of ancient DNA in thermally damaged archeological bone, Naturwissenschaften 96/2, 2009, 267-278.

Parker Pearson 1999

M. Parker Pearson, The Archaeology of Death and Burial. Stroud 1999.

Parker Pearson et al. 2005

M. Parker Pearson, A. Chamberlain, O. Craig, P. Marshall, J. Mulville, H. Smith, C. Chenery, M. Collins, G. Cook, G. Craig, J. Evans, J. Hiller, J. Montgomery, J.-L. SchwenNINGER, G. TAYlor, T. Wess, Evidence for mummification in Bronze Age Britain, Antiquity 79/305, 2005, 529-546.

Parker Pearson et al. 2007

M. Parker Pearson, A. Chamberlain, M. Collins, C. Cox, G. Craig, O. Craig, J. Hiller, P. Marshall, J. Mulville, H. SмITH, Further evidence for mummification in Bronze Age Britain, Antiquity 81/312, 2007, Project Gallery, http://antiquity.ac.uk/projgall/parker312/ (last accessed 22.6.2017).

Parker Pearson et al. 2013

M. Parker Pearson, C. Cox Willis, P. Marshall, J. Mulville, H. Smith, T. Cowie, O. Craig, I. Deluis, M. Juddery, H. Manley, J.-L Schwenninger, G. TAylor, After the 'Frankenstein mummies': Cladh Hallan in the Bronze and Iron ages, Past 73, 2013, 11-13.

Pfeiffer 2000

S. Pfeiffer, Paleohistology: health and disease. In: A. Katzenberg, S. SAUnders (Eds.) Biological Anthropology of the Human Skeleton. New York 2000, 287-302.

PiePENBRINK 1984

H. Piepenbrink, Beispiele biogener Dekompositionserscheinungen an Knochen unter längerer Liegezeit, Anthropologischer Anzeiger 42/4, 1984, 241-251.

Piepenbrink 1986

H. Piependrink, Prinzipien der Knochendekomposition und ihre Konsequenzen für die diagnostische Bearbeitung von Skelettfunden. In: B. HänSEL, B. Herrmann (Eds.), Innovative Trends in der prähistorischen Anthropologie. Beiträge zu einem internationalen Symposium vom 26. Februar bis 1. März 1986 in Berlin (West). Mitteilungen der Berliner Gesellschaft für Anthropologie, Ethnologie und Urgeschichte 7, 1986, 15-21.

Pilloud et al. 2016

M. A. Pilloud, S. D. Haddow, C. J. Knüsel, C. S. Larsen, A bioarchaeological and forensic re-assessment of vulture defleshing and mortuary practices at Neolithic Çatalhöyük, Journal of Archaeological Science: Reports 10, 2016, 735-743.

POSNER 1969

A. S. Posner, Crystal chemistry of bone mineral, Physiological Reviews 49/4, 1969, 760-792.

REICHERT 2018

A. Reichert, Baumrinden und Zwirngeflechtsmuster, Anzeiger EAS Experimentelle Archäologie Schweiz / Bulletin AES Archéologie Expérimentale Suisse 2018, 18-19.

Reiter, Ilbeygui, Stein 2007

C. Reiter, R. Ilbeygui, C. Stein, Synopsis und Atlas der Gerichtsmedizin, third revised edition. Vienna 2007.

\section{Rodriguez, Bass 1983}

W. C. Rodriguez, W. M. BAss, Insect activity and its relationship to decay rates of human cadavers in East Tennessee, Journal of Forensic Science 28/2, 1983, 423-432.

RösING 1988

F. W. RösıNG, Körperhöhenrekonstruktion aus Skelettmaßen. In: R. Knussmann (Ed.), Anthropologie: Handbuch der vergleichenden Biologie des Menschen, Vol. 1/1: Wesen und Methoden der Anthropologie. Stuttgart 1988, 586-600.

SCHEDEL 2012

K. SCHEDEL, Bakterizide und antiadhäsive Wirkung von Kupferbeschichtungen auf Silikonbrustimplantaten. PhD Dissertation, University of Regensburg 2012, http://urn:nbn:de:bvb:355epub-243154 (last accessed 15.4.2018).

SCHERER 2015

A. K. SCHERER, Mortuary Landscapes of the Classic Maya: Rituals of Body and Soul. Austin 2015.

SCHULTZ 1997

M. Schultz, Microscopic investigation of excavated skeletal remains: a contribution to paleopathology and forensic medicine. In: W. D. Haglund, M. H. Sorg (Eds.), Forensic Taphonomy: The Postmortem Fate of Human Remains. Boca Raton 1997, 201-222.

Schultz, Teschler-Nicola 1989

M. Schultz, M. Teschler-Nicola, Osteologische Untersuchungen an bronzezeitlichen Kinderskeletten aus Franzhausen, Niederösterreich, Verhandlungen der Anatomischen Gesellschaft 82, 1989, 407-409.

Simmons et al. 2010

T. Simmons, P. A. Cross, R. E. Adlam, C. Moffatt, The influence of insects on decomposition rate in buried and surface remains, Journal of Forensic Science 55/4, 2010, 889-892.

SJøVOLD 1988

T. Sృøvold, Geschlechtsdiagnose am Skelett. In: R. Knussmann (Ed.), Anthropologie: Handbuch der vergleichenden Biologie des Menschen, Vol. 1/1: Wesen und Methoden der Anthropologie, Stuttgart 1988, 444-480.

SMITH et al. 2007

C. I. Smith, C. M. Nielsen-Marsh, M. M. E. Jans, M. J. Collins, Bone diagenesis in European Holocene I: patterns and mechanisms, Journal of Archaeological Science 34/9, 2007, 1485-1493.

SMITH et al. 2016

M. J. Smith, M. J.Allen, G. Delbarre, T. Booth, P. Cheetham, L. Bailey, F. O’Malley, M. Parker Pearson, M. Green, Holding on to the past: southern British evidence for mummification and retention of the dead in the Chalcolithic and Bronze Age, Journal of Archaeological Science: Reports 10, 2016, 744-756.

Sosa et al. 2013

C. Sosa, E. Vispe, C. Núñez, M. Baeta, Y. Casalod, M. Bolea, R. E. M. Hedges, B. Martínez-Jarreta, Association between ancient bone preservation and DNA yield: a multidisciplinary approach, American Journal of Physical Anthropology 151/1, 2013, 102-109.

SPATZIER 2007

A. SpatZier, Untersuchungen zu Chronologie, Grabstörung und Struktur des frühbronzezeitlichen Gräberfeldes Franzhausen I, Niederösterreich, Prähistorische Zeitschrift 82/2, 2007, 215-247.

Sprague 2005

R. Sprague, Burial Terminology: A Guide for Researchers. Lanham 2005. 


\section{SPRENGER 1999}

S. SPREnger, Zur Bedeutung des Grabraubes für sozio-archäologische Gräberfeldanalysen: Eine Untersuchung am frühbronzezeitlichen Gräberfeld Franzhausen I, Niederösterreich. Fundberichte aus Österreich, Materialhefte A 7, Vienna 1999.

STADLER 2001

P. STADLER, Gegenwärtiger Stand der Auswertung der archäologischen und anthropologischen Daten aus dem frühbronzezeitlichen Gräberfeld Franzhausen I mithilfe der „Analyse der Nächsten Nachbarn“. In: A. Lippert, M. Schultz, S. Shennan, M. Teschler-Nicola (Eds.), Mensch und Umwelt während des Neolithikums und der Frühbronzezeit in Mitteleuropa: Ergebnisse interdisziplinärer Archäologie, Klimatologie, Biologie und Medizin. Internationale Archäologie, Arbeitsgemeinschaft, Symposium, Tagung, Kongress 2, Rahden/Westf., 2001, 257-270.

STOCKHAMmer et al. 2015

P. W. Stockhammer, K. Massy, C. Knipper, R. Friedrich, B. Kromer, S. Lindauer, J. Radosavljević, F. Wittenborn, J. Krause, Rewriting the central European Early Bronze Age chronology: evidence from large-scale radiocarbon dating, PLoS ONE 10/10, 2015, e0139705. doi: 10.1371/journal.pone.0139705

STRAHM 2002

C. Strahm, Tradition und Wandel der sozialen Strukturen vom 3. zum 2. vorchristlichen Jahrtausend. In: J. MülLER (Ed.), Vom Endneolithikum zur Frühbronzezeit: Muster sozialen Wandels? Tagung Bamberg 14.-16. Juni 2001. Universitätsforschungen zur prähistorischen Archäologie 90, Bonn 2002, 175-194.

SZILVÁsSY I 988

J. Szilvássy, Altersdiagnose am Skelett. In: R. Knussmann (Ed.), Anthropologie: Handbuch der vergleichenden Biologie des Menschen. Bd. 1/1: Wesen und Methoden der Anthropologie, Stuttgart 1988, 421-443.

Teschler-Nicola 1988

M. Teschler-Nicola, Franzhausen I - Bevölkerungsbiologie der Bronzezeit. In: H. J. Winde, J.-W. Neugebauer, M. TeschlerNicola, C. Neugebauer-Maresch (Eds.), Mensch und Kultur der Bronzezeit - Franzhausen I, Gemeinde Nußdorf ob der Traisen, NÖ: Mitteleuropas größtes frühbronzezeitliches Hockergräberfeld, Katalog des Niederösterreichischen Landesmuseum N. F. 208 Asparn/Zaya, 1988, 37-65.

Teschler-Nicola 1992

M. Teschler-Nicola, Sexualdimorphismus der Zahnkronendurchmesser: Ein Beitrag zur Geschlechtsdiagnose subadulter Individuen anhand des frühbronzezeitlichen Gräberfeldes von Franzhausen I, Niederösterreich, Anthropologischer Anzeiger 50/1-2, 1992, 51-65.

TURNER-WALKER 2008

G. Turner-Walker, The chemical and microbial degradation of bones and teeth. In: R. PINHASI, S. Mays (Eds.), Advances in Human Palaeopathology, West Sussex 2008, 3-29.

Turner-Walker, Mays 2008

G. Turner-Walker, S. Mays, Histological studies on ancient Bone. In: R. Pinhasi, S. Mays (Eds.), Advances in Human Palaeopathology, West Sussex 2008, 121-146.

Turner-Walker, Peacock 2008

G. Turner-Walker, E. E. Peacock, Preliminary results of bone diagenesis in Scandanavian bogs, Palaeogeography, Palaeoclimatology, Palaeoecology 266/3-4, 2008, 151-159.
URBAN 2000

O. Urban, Der lange Weg zur Geschichte: Die Urgeschichte Österreichs. Vienna 2000.

Usai et al. 2014

M. R. Usai, M. D. Pickering, C. A. Wilson, B. J. Keely, D. R. BRothWELL, 'Interred with their bones': soil micromorphology and chemistry in the study of human remains, Antiquity 88/339, 2014, Project Gallery, http://antiquity.ac.uk/projgall/ usai339/ (last accessed 18.6.2017).

VAN DER REST 1991

M. VAN DER Rest, The collagens of bone. In: B. K. Hall (Ed.), Bone, Vol. 3: Matrix and Bone Specific Products. London 1991, 187238.

WEDL 1865

C. WeDL, Über einen im Zahnbein und Knochen keimenden Pilz, Sitzungsberichte der mathematisch-naturwissenschaftlichen Classe der Kaiserlichen Akademie der Wissenschaften, 50/1864, 1865, 171-193.

Weiss-KrejCi 2011a

E. WeIss-KrejCI, The formation of mortuary deposits: implications for understanding mortuary behavior of past populations. In: S. C. Agarwal, B. Glencross (Eds.), Social Bioarchaeology. Blackwell Studies in Global Archaeology, Chichester 2011, 68-106.

Weiss-KrejCi 2011b

E. Weiss-Krejci, Changing perspectives on mortuary practices in Late Neolithic/Copper Age and Early Bronze Age Iberia. In: K. Lillios (Ed.), Comparative Archaeologies: Prehistoric Iberia (3000-1500BC) and the American Southwest (A.D. 900-1600). Oxford 2011, 153-174.

WeISS-KREJCI 2013

E. Weiss-Krejci, The unburied dead. In: S. Tarlow, L. Nilsson STUTz (Eds.), The Oxford Handbook of the Archaeology of Death and Burial. Oxford 2013, 281-301.

White, Воотн 2014

L. White, T. J. Bоотн, The origin of bacteria responsible for bioerosion to the internal bone microstructure: results from experimentally-deposited pig carcasses, Forensic Science International 239, 2014, 92-102.

White, Folkens 2005

T. D. White, P. A. Folkens, The Human Bone Manual. London 2005.

White, Black, Folkens 2005

T. D. White, M. T. Black, P. A. Folkens, Human Osteology, third edition. Amsterdam 2012.

WiKTOROWICZ et al. 2017

C. J. Wiktorowicz, B. Arnold, J. E. Wiktorowicz, M. L. Murray, A. Kurosky, Hemorrhagic fever virus, human blood, and tissue in Iron Age mortuary vessels, Journal of Archaeological Science 78, 2017, 29-39.

WILSON 2007

J.E.P. Wilson, The social role of the elderly in the Early Bronze Age of central Europe. Unpublished PhD Dissertation, University of Cambridge 2007.

WiltschKe-SCHROTTA 1988

K. WiltschKe-Schrotta, Das frühbronzezeitliche Gräberfeld von Franzhausen I: Analyse der morphologischen Merkmale mit besonderer Berücksichtigung der epigenetischen Varianten. Unpublished PhD Dissertation, University of Vienna 1988. 
WiLTSCHKE-SCHROTTA 1992

K. Wiltschke-SchrotTA, Das frühbronzezeitliche Gräberfeld von Franzhausen I, Niederösterreich 3: Untersuchung der epigenetischen Merkmale, Anthropologischer Anzeiger 50/1-2, 1992, 27-49.

WoLfF-HeIDEgGer 1954

G. Wolff-Heidegger, Atlas der systematischen Anatomie des Menschen, Vol. 1, Basel - New York 1954.

Yamada, Kudou, Takahashi-Iwanaga 1990

T. K. Yamada, T. Kudou, H. Takahashi-Iwanaga, Some 320-yearold soft tissue preserved by the presence of mercury, Journal of Archaeological Science 17/4, 1990, 383-392.

Yoshino et al. 1991

M. Yoshino, T. Kimijima, S. Miyasaka, H. Sato, S. Seta, Microscopical study on time since death in skeletal remains, Forensic Science International 49/2, 1991, 143-158.

$$
\begin{array}{r}
\text { Kirsten Mandl } \\
\text { Department of Evolutionary Antbropology } \\
\text { University of Vienna } \\
\text { Althanstraße 14 (UZA I) } \\
1090 \text { Vienna } \\
\text { Austria } \\
\text { kirsten.mandl@univie.ac.at } \\
\text { Friederike Novotny } \\
\text { orcid.org/0000-0002-2078-0775 } \\
\text { Department of Antbropology } \\
\text { Natural History Museum Vienna } \\
\text { Burgring } 7 \\
1010 \text { Vienna } \\
\text { Austria } \\
\text { friederike.novotny@nbm-wien.ac.at } \\
\text { (D) orcid.org/0000-0001-7368-2020 } \\
\text { Maria Teschler-Nicola } \\
\text { Department of Antbropology } \\
\text { Natural History Museum Vienna } \\
\text { Burgring } 7 \\
1010 \text { Vienna } \\
\text { Austria } \\
\text { (D) orcid.org/0000-0003-3080-3085 }
\end{array}
$$

Estella Weiss-Krejci
Institute for Oriental and European Archaeology
Austrian Academy of Sciences
Hollandstraße 11-13
1020 Vienna
Austria
estella.weiss-krejci@oeaw.ac.at
(D) orcid.org/0000-0002-9762-2038


